\title{
Space Suit Portable Life Support System Rapid Cycle Amine Repackaging and Sub-Scale Test
} Results

\author{
Heather L. Paul \\ NASA Johnson Space Center, Houston, TX
}

Fatonia L. Rivera

Jacobs Technology, Houston, TX

\begin{abstract}
NASA is developing technologies to meet requirements for an extravehicular activity (EVA) Portable Life Support System (PLSS) for exploration. The PLSS Ventilation Subsystem transports clean, conditioned oxygen to the pressure garment for space suit pressurization and human consumption, and recycles the ventilation gas, removing carbon dioxide, humidity, and trace contaminants. This paper provides an overview of the development efforts conducted at the NASA Johnson Space Center to redesign the Rapid Cycle Amine (RCA) canister and valve assembly into a radial flow, cylindrical package for carbon dioxide and humidity control of the PLSS ventilation loop. Future work is also discussed.
\end{abstract}

\section{Introduction}

Technology development activities to redesign the Portable Life Support System (PLSS) have emphasized the need for lighter mass, smaller volume, more efficient systems that require less consumables usage and are reliable, robust, and require low power. Within the space suit volume, control of carbon dioxide and humidity levels is critical to ensure safety and health of the crewmember and the space suit systems.

The rapid cycle amine (RCA) swing bed technology has been developed to provide on-back, real-time, carbon dioxide $\left(\mathrm{CO}_{2}\right)$ and humidity control for the space suit system via a vacuumregenerable amine sorbent. Previous development efforts resulted in a rectangular canister design with a pneumatic spool valve [1,2], to be referred to as the "HS RCA" in this paper. This development effort demonstrated that the system, when filled with a solid amine sorbent, SA9T, could be regenerated via pressure swing. Figure 1 shows a simplified schematic of the RCA operation, with the use of two adjacent sorbent beds. While one bed adsorbs $\mathrm{CO}_{2}$ and water $\left(\mathrm{H}_{2} \mathrm{O}\right)$ from the ventilation loop, the other can be regenerated by vacuum exposure or inert sweep gas. Once the adsorbing bed reaches capacity, the flow is switched via the spool valve to the regenerated sorbent bed and the "full" bed is exposed to vacuum or inert gas for regeneration. Figure 2 (left) shows the HS RCA assembly including the 2-bed, 4-layer canister and pneumatic spool valve. Figure 2 (right) shows the internal view of an amine bed layer, with three foam segments per layer, thus this system is considered a " $3 \times 4$ array" as it has three foam segments and four layers. This technology development effort proved that a lower weight design could successfully meet the requirements for $\mathrm{CO}_{2}$ and $\mathrm{H}_{2} \mathrm{O}$ control. The final total system weight was $3.84 \mathrm{~kg}$. 


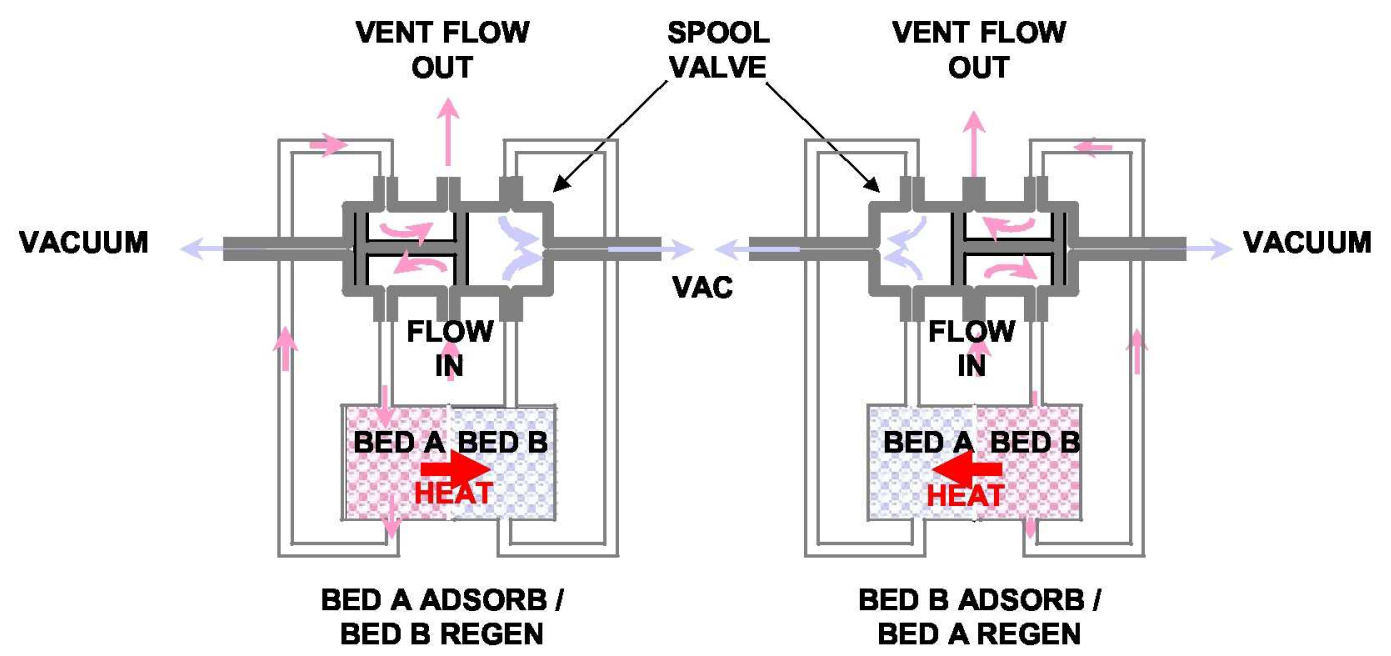

Figure 1. Flow Schematic of the RCA
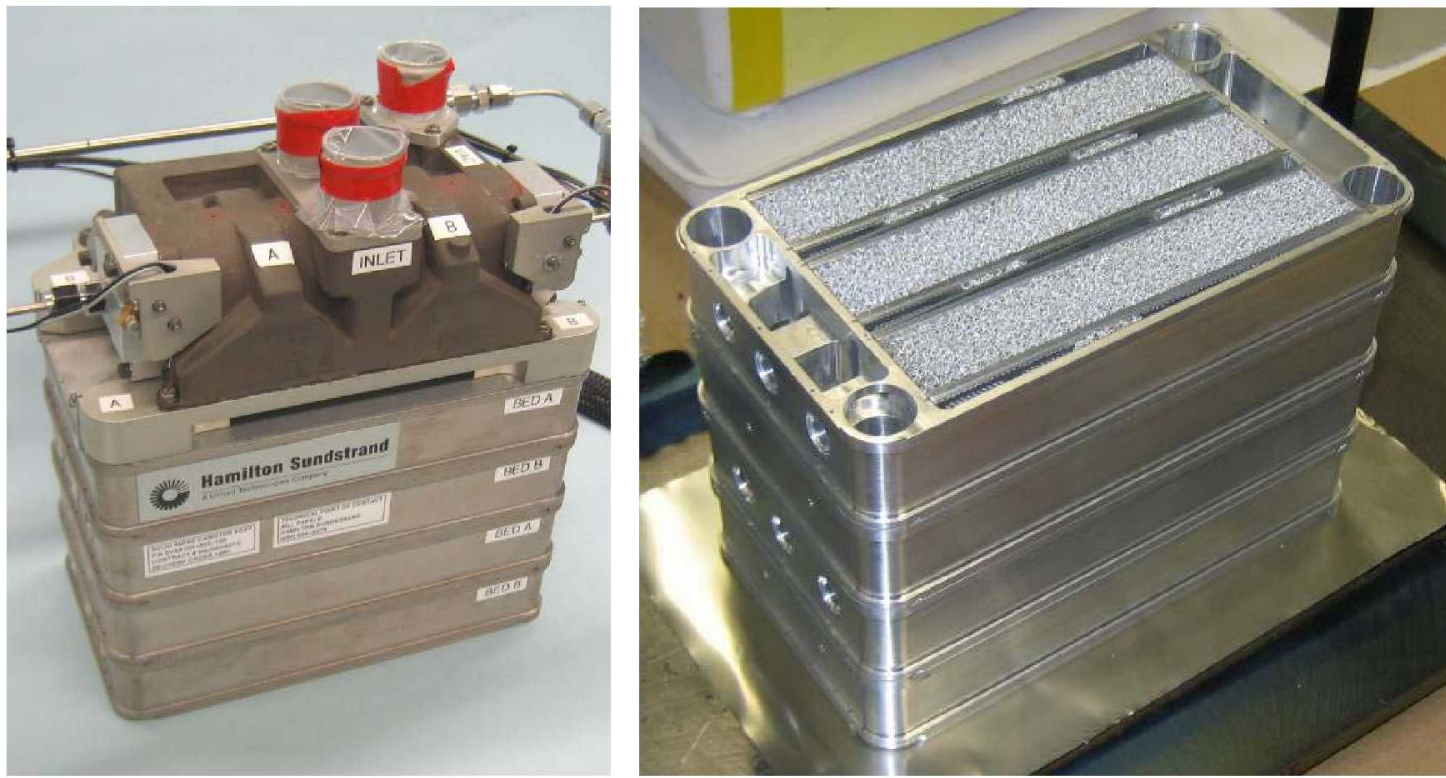

Figure 2. HS RCA system (left) and internal view showing the 4 Layer Brazed Assembly with 2 Layers Per Sorbent Bed and 3 Foam Segments Per Layer (right)

\section{Rapid Cycle Amine Repackaging}

Further efforts to repackage the PLSS architecture to minimize weight, volume, and power, indicated that the rectangular canister design with a $3 \times 4$ array was not optimal. A design assessment revealed that moving towards a taller, thinner profile assembly would fit better into the PLSS package, therefore a reduced profile, $2 \times 6$ array, RCA assembly was designed, incorporating 2 foam segments per layer with six layers overall. Figure 3 shows a comparison of the rectangular HS RCA canister design (left) and the reduced profile design (right). Figure 4 shows the reduced profile design incorporated into the Phase II PLSS package. 

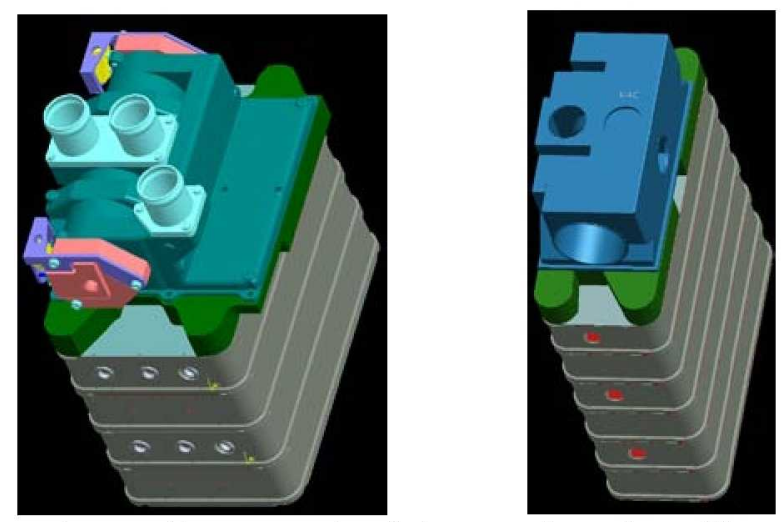

Figure 3. Left - HS RCA (3x4 array); Right - Reduced Profile RCA (2x6 array)
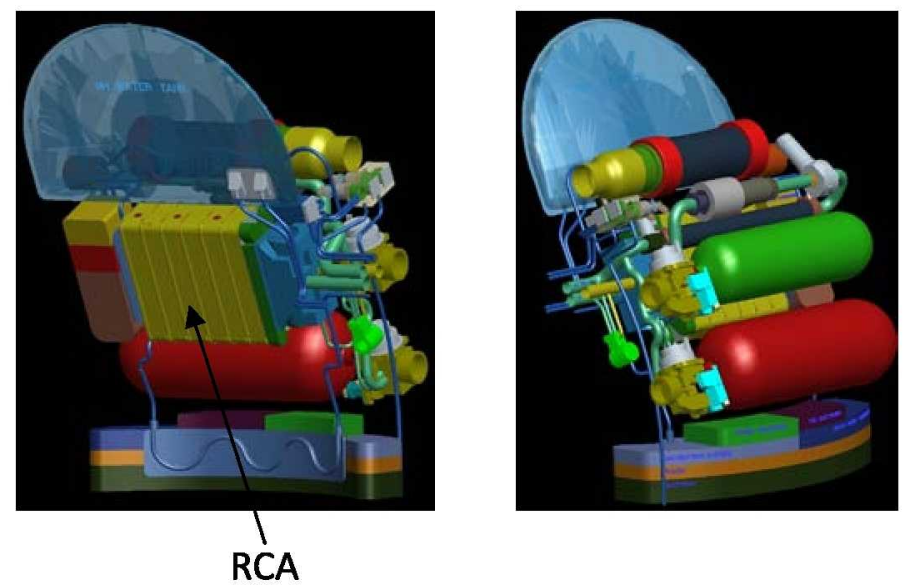

Figure 4. Reduced Profile RCA integrated into the PLSS Package

Therefore, the next phase of RCA development focused on redesigning the RCA assembly into a lighter weight, compact design that would better fit into the redesigned PLSS package compared to the HS RCA rectangular canister design. Both canister and valve design concepts were developed to evaluate technology and material options, manufacturing techniques, and assembly methods to determine if further redesign would reveal a more efficient, lightweight, low volume, low power system. Brainstorming sessions led to the creation of 55 bed design concepts, with more than 16 material possibilities, 27 manufacturing and assembly processes, 31 overall geometry options for the assembly, 19 geometry options for the valve, and 24 geometry options for the canister.

These concepts were then compared and down-selected to create five canister concepts and four valve concepts for further evaluation. Two of the canister designs maintained the reduced profile, $2 \times 6$ array, but traded brazing versus bolting as the assembly method. A dual bed riveted, or "clamshell," canister design was a $6 \times 2$ array that evaluated riveting as the assembly method. To reduce the profile further, a single level "radiator" canister approach was also evaluated. And finally, a cylindrical "Gatling" canister design was investigated to break from the traditional "rectangular" canister concepts. The relative size comparisons of the canister 
concepts are shown in Figures 5 and 6 . Four valve concepts were traded including a linear spool valve with a cast housing, a linear spool valve with a machined housing, a rotary ball valve, and a rotary "Gatling" valve for the cylindrical canister concept.

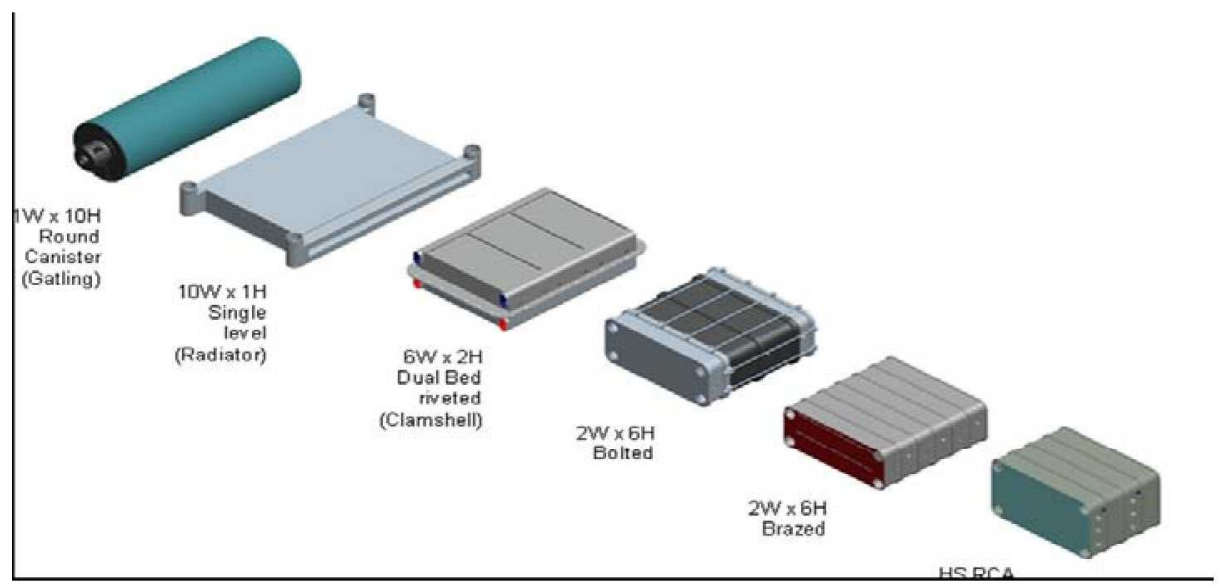

Figure 5. Relative Size Comparison of the Six RCA Canister Concepts

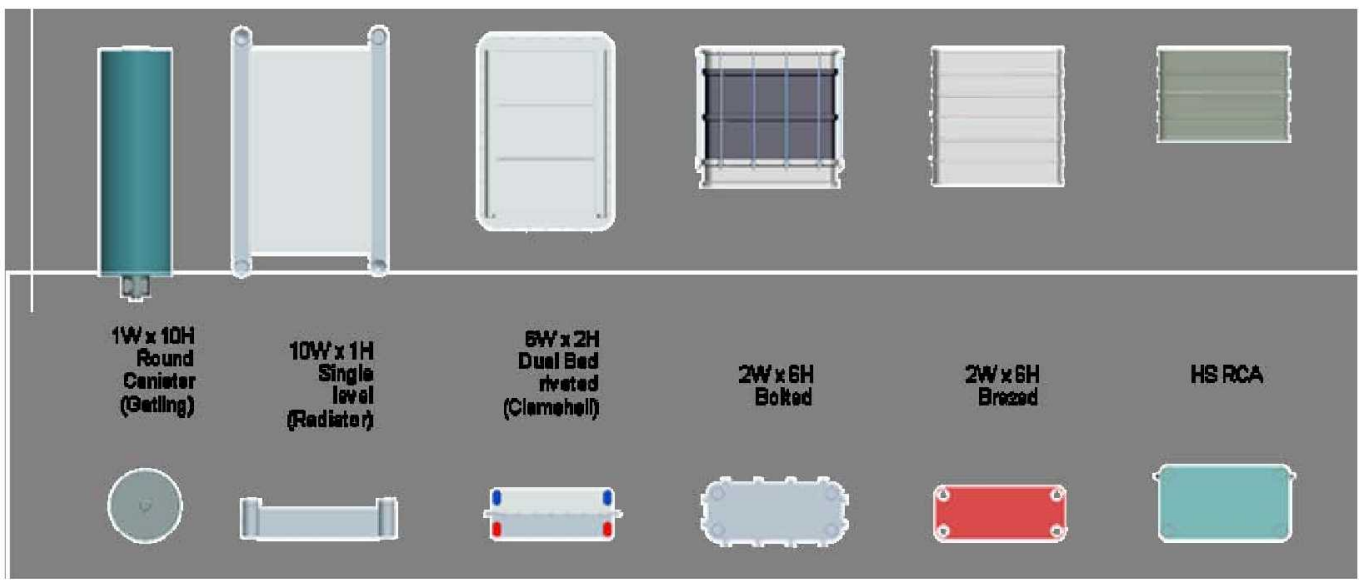

Figure 6. Top View Size Comparison of the Six RCA Canister Concepts

Each of the concepts was assessed and ranked according to predictions on assembly mass, assembly volume, reliability, part count, flow and thermal performance, and manufacturability. The results of the rankings revealed that the cylindrical design with a "Gatling" valve was the best option so it was chosen for further development. Figure 7 shows the full-scale RCA conceptual design with the cylindrical canister and rotary "Gatling" valve. Figure 8 shows the cylindrical RCA flow path and 90-degree valve rotation and Figure 9 shows the valve rotation. 


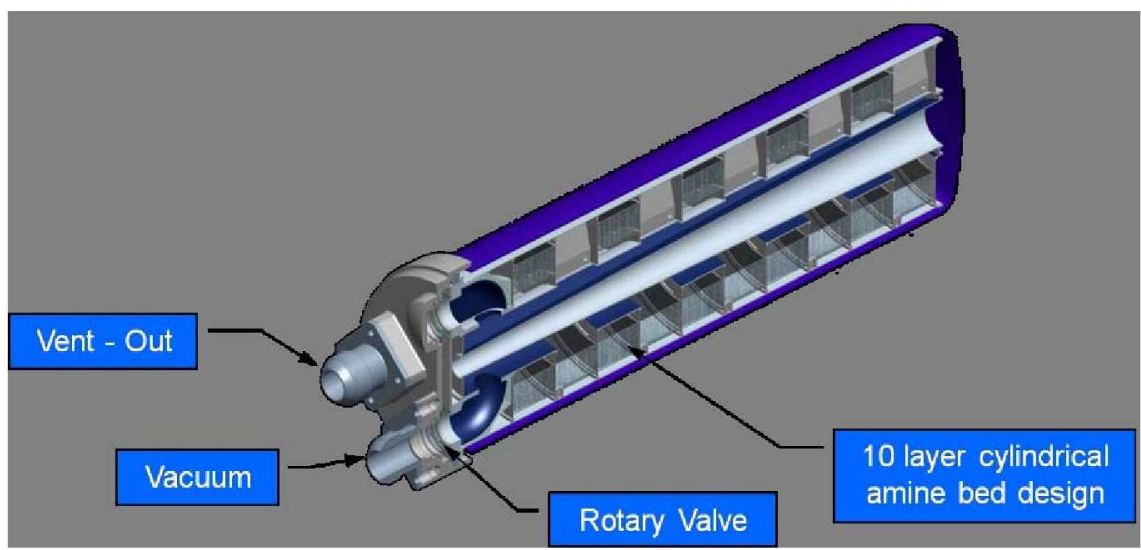

Figure 7. Full-scale conceptual design for the cylindrical RCA assembly

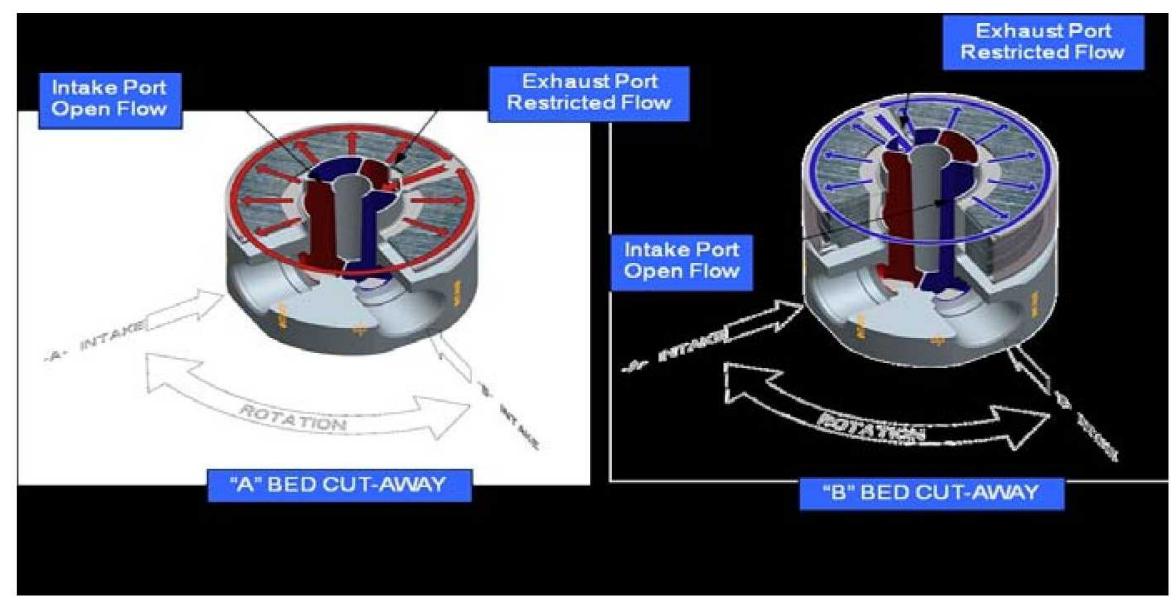

Figure 8. The cylindrical RCA flow path and valve rotation

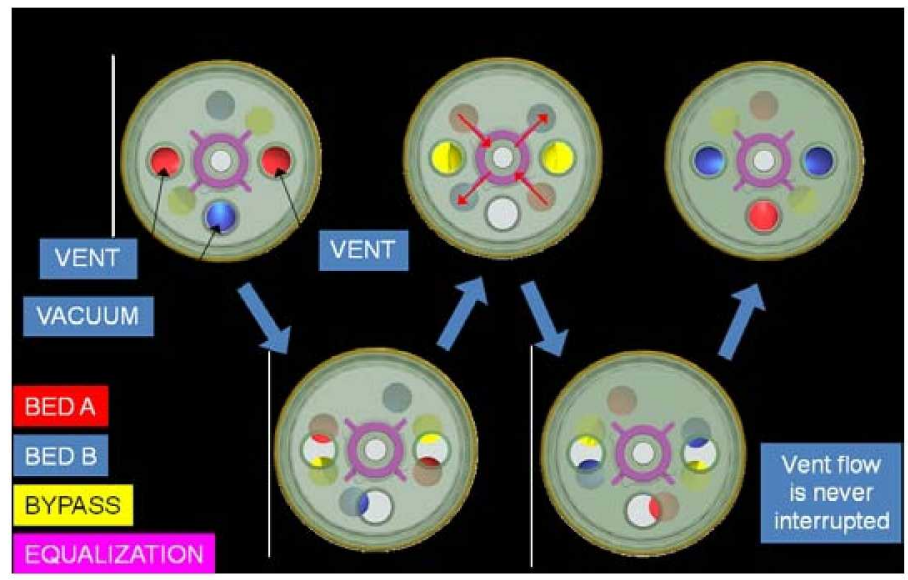

Figure 9. RCA Valve Rotation 


\section{Sub-Scale Test Articles and Test Results}

While brainstorming and developing conceptual designs led to the decision to proceed with a cylindrical RCA assembly, this decision came with the understanding that this would be a high-risk development effort. As this assembly is simultaneously subjected to ventilation loop pressure and ambient vacuum, there is an inherent risk of subjecting the crewmember to vacuum if the design fails due to manufacturing and/or assembly issues. Additionally, while preliminary analysis predictions showed that the radial-flow assembly would control $\mathrm{CO}_{2}$ and $\mathrm{H}_{2} \mathrm{O}$ more efficiently than the HS RCA, this would need to be proven. Rather than immediately designing and building a full-scale assembly, NASA decided to develop a series of sub-scale test articles, each of which addressed a specific risk identified for the overall assembly.

Four sub-scale test articles were developed as shown in Figure 10. Test Article 1 (TA1) evaluated methods for joining the RCA end caps to the cylindrical bed housing interface. Test Article 2 (TA2) evaluated the manufacturing and assembly of a two bed, four layer cylindrical RCA canister. Test Article 3 (TA3) focused on the amine fill process and flow visualization of the gas through the cylindrical amine beds. Test Article 4 (TA4) assessed the feasibility of the face seal valve design, testing the mechanical forces required to rotate the valve and the clamping forces required to prevent leakage during valve rotation. TA4 also assessed wear on the proposed RCA face seal between the rotating bed assembly and the fixed outer structure. This section of the paper focuses on TA4 and its test results.

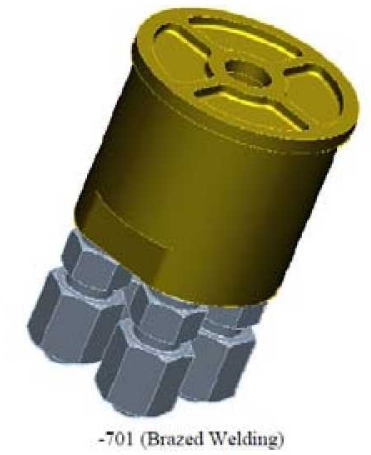

TA1-Brazed and TA1-EBW
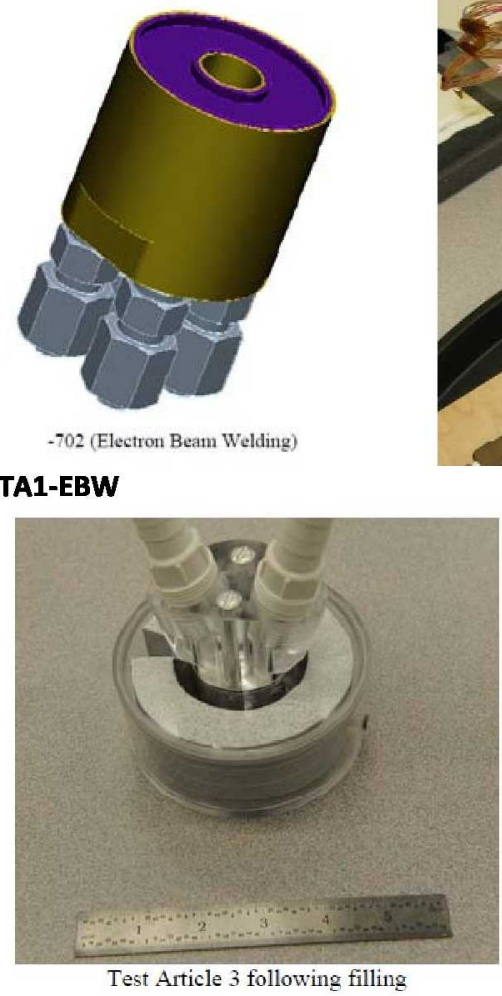

TA3

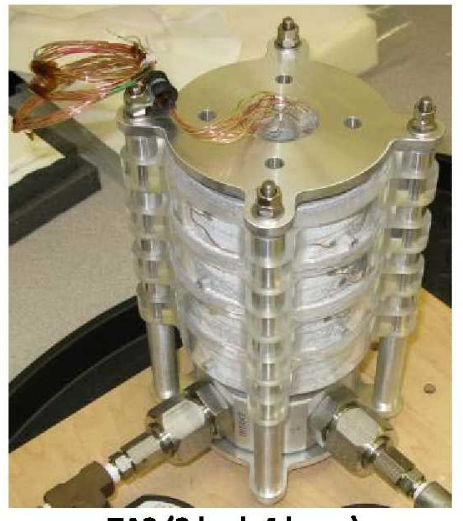

TA2 (2 bed, 4 layer)

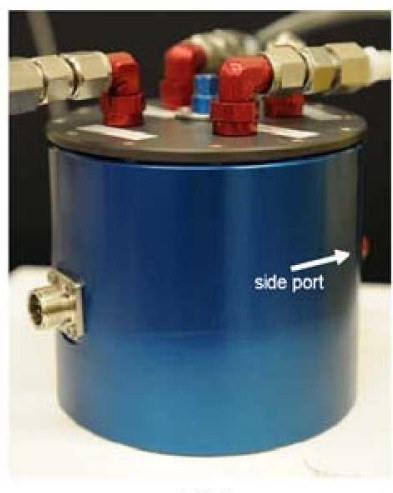

TA4

Figure 10. The Four Sub-Scale RCA Test Articles 


\section{$\underline{\text { Test Article } 4 \text { Design and Test Objectives }}$}

NASA designed a rotary valve with a face seal to cycle the ventilation loop and vacuum flow paths to the respective adsorb and desorb beds of the cylindrical RCA canister. TA4, the Face Seal Test Article, was manufactured to demonstrate the basic feasibility and operability of the rotary face seal valve design. TA4 consisted of a ventilation port plate assembly and an enclosure assembly as shown in Figure 11.

The enclosure assembly housed the bed simulator assembly, load cell, and clamping bolt. This assembly represented the size of two amine bed layers and was tightly sealed with an O-ring and a port plate assembly. The TA4 bed simulator assembly had individual pressure chambers for each hole of the face seal. The clamping bolt was used to set the overall clamping pressure and a load cell measured the clamping force on the valve [3].

A full-sized face seal was installed on the bed simulator assembly as shown in Figure 12. The face seal was a custom design consisting of a Nitrile N406-60 Gasket-O-Seal within a polished aluminum disk. Rotation of the face seal occurred by applying torque to the hexagonal bolt in the center of the top face of TA4. This hexagonal fitting protruded from the top of the test article (Figures 11, 12, \& 13) and it also acted as a position indicator. The simulated positions were " $A$ " or " $B$ " for the two amine beds, and position " $O$ " for the RCA bypass setting (Figure 13). The face seal was tightened to the assembly by applying torque to the clamping bolt located underneath the enclosure assembly of the TA4 unit (Figure 11).

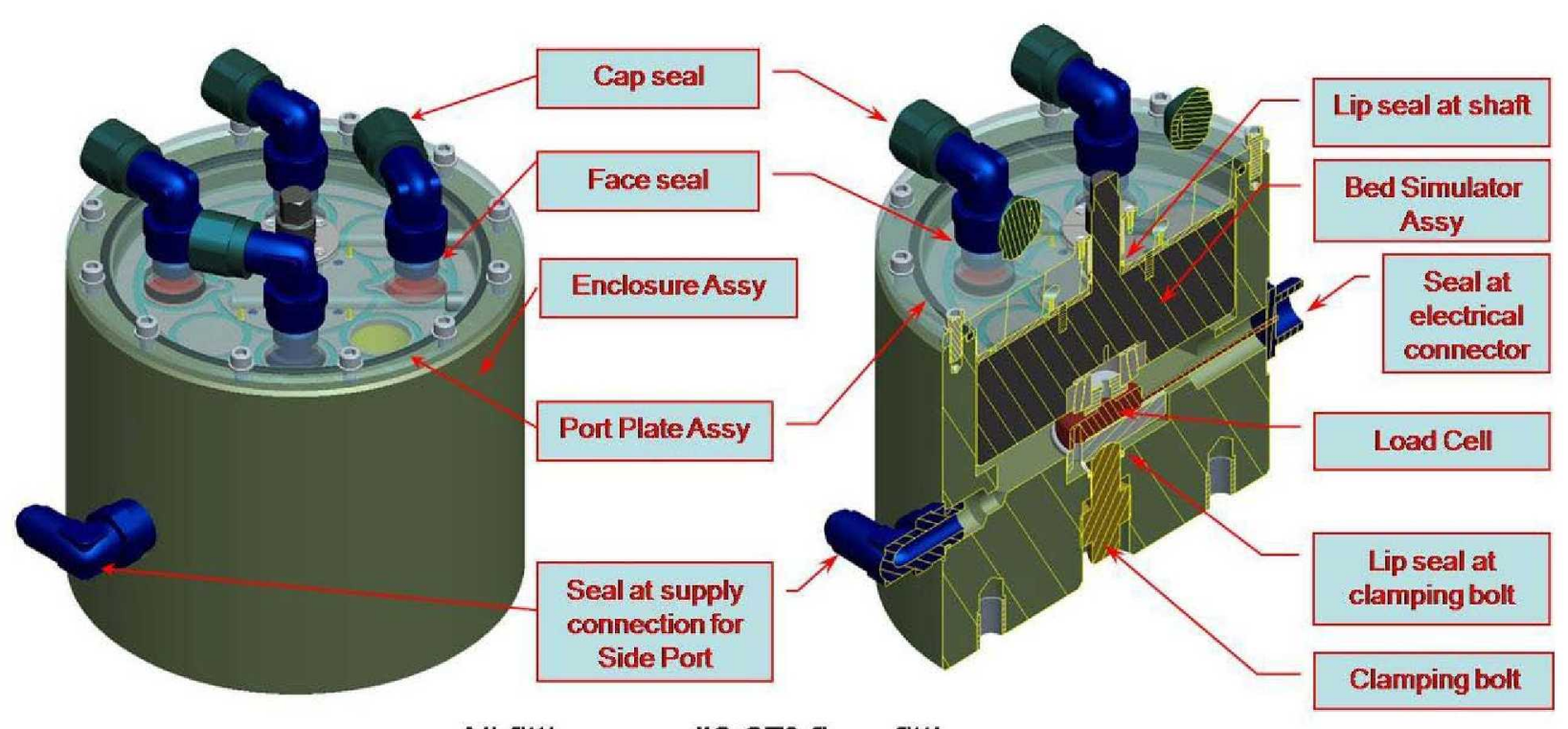

All fittings are \#6 $37^{\circ}$ flare fittings

Figure 11. Face Seal Test Article 4 and Its Major Components 

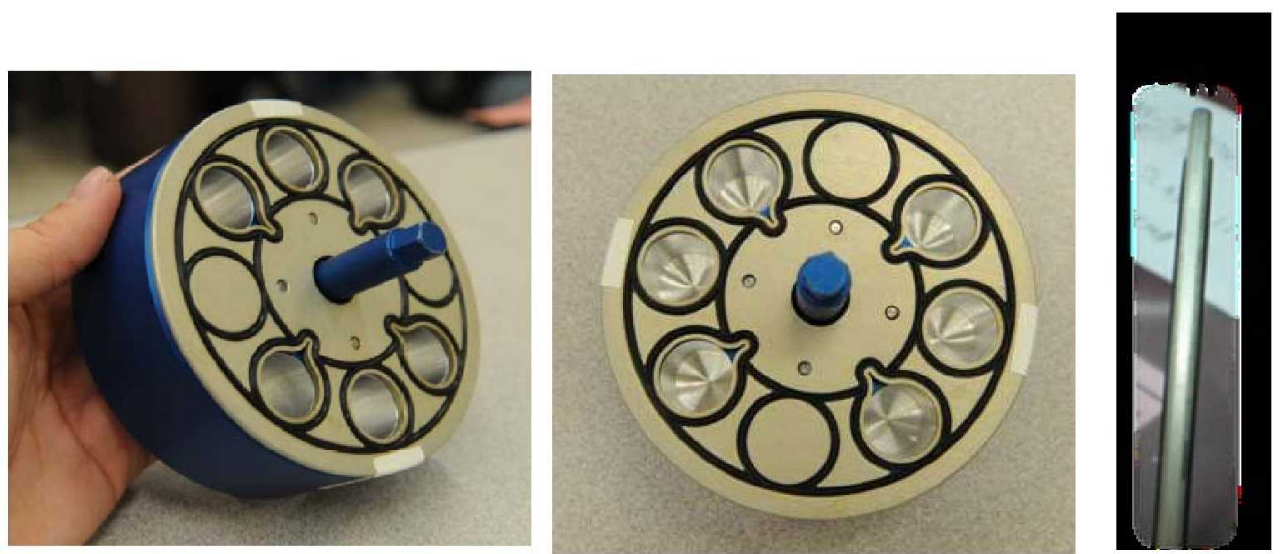

Figure 12. The rotary face seal installed on Test Article 4 bed simulator (left, center) and the edge view of face seal (right)

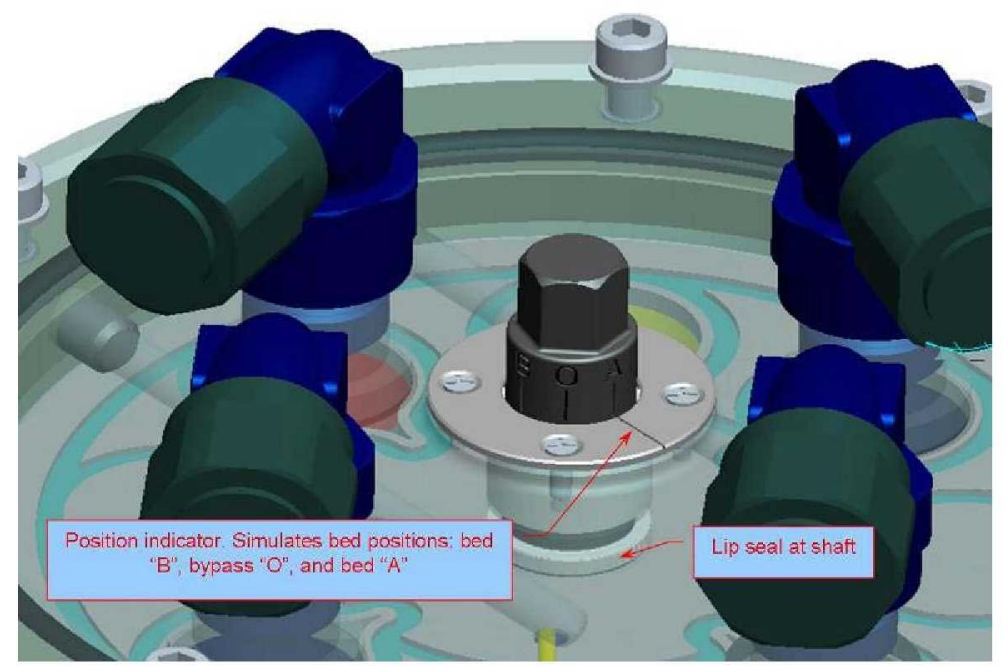

Figure 13. Top view details of Test Article

\section{Test Article 4 Test Operations and Results}

TA4 testing had two phases and several objectives. Phase 1 testing had three test objectives: 1) characterize leak rate about the face seal versus clamping force, 2 ) identify actuation torque versus clamping force, and 3) perform a visual assessment of the face seal wear due to rotating the face seal against the port plate. In Phase 2, the test objectives were the same as in Phase 1, but Phase 2 also performed a series of tests to measure the full compression load deflection and compression set of the face seal to characterize the seal material.

After assembling TA4 as shown in Figures 10 and 11, the test article was examined for leakage through its exterior seals, so that any leakage observed in later test objectives could be attributed solely to face seal leakage and not to the exterior seals. The load cell within TA4 was completely unloaded and TA4 was pressurized to 16 psig with nitrogen gas. The test article was then submerged in water and any bubbles escaping TA4 were measured with inverted graduate cylinders submerged partially in water. Leakage was observed at the TA4 top and bottom lip seals. The top lip seal was located around the hexagonal fitting (Figure 13) and the bottom lip seal was located around the clamping bolt (Figure 11). 
The leakage volumetric flow rates measured for the top and bottom lip seal were $6.6 \mathrm{~mL} / \mathrm{min}$ and 9.6 $\mathrm{mL} / \mathrm{min}$, respectfully [3]. This leakage was deemed acceptable to proceed to the torque testing to evaluate any operability of the rotary valve design. In Phase 2, this test objective would be repeated, but only allowing smaller leakage rates to occur before proceeding to the torque testing.

To achieve test objectives 1 and 2, the leak rate as a function of clamping force and actuation torque as a function of clamping force were measured simultaneously by using an in-line torque meter while rotating the rotary valve between the " $A$ " and " $B$ " position settings. In both cases, the clamping force was varied by increasing the clamping bolt force in $5 \mathrm{lbf}$ increments until the desired characterizations could be accomplished.

The test setup is presented in Figure 14. These tests were conducted with the test article at 4.3-4.8 psig or 16 psig, via the nitrogen gas supply. The load cell quantified the applied clamping force. Gas leakage was noted and the leakage locations were recorded (Tables 1 and 2). When gas leakage was no longer observed, the running and breakaway torques were measured at that clamping force.

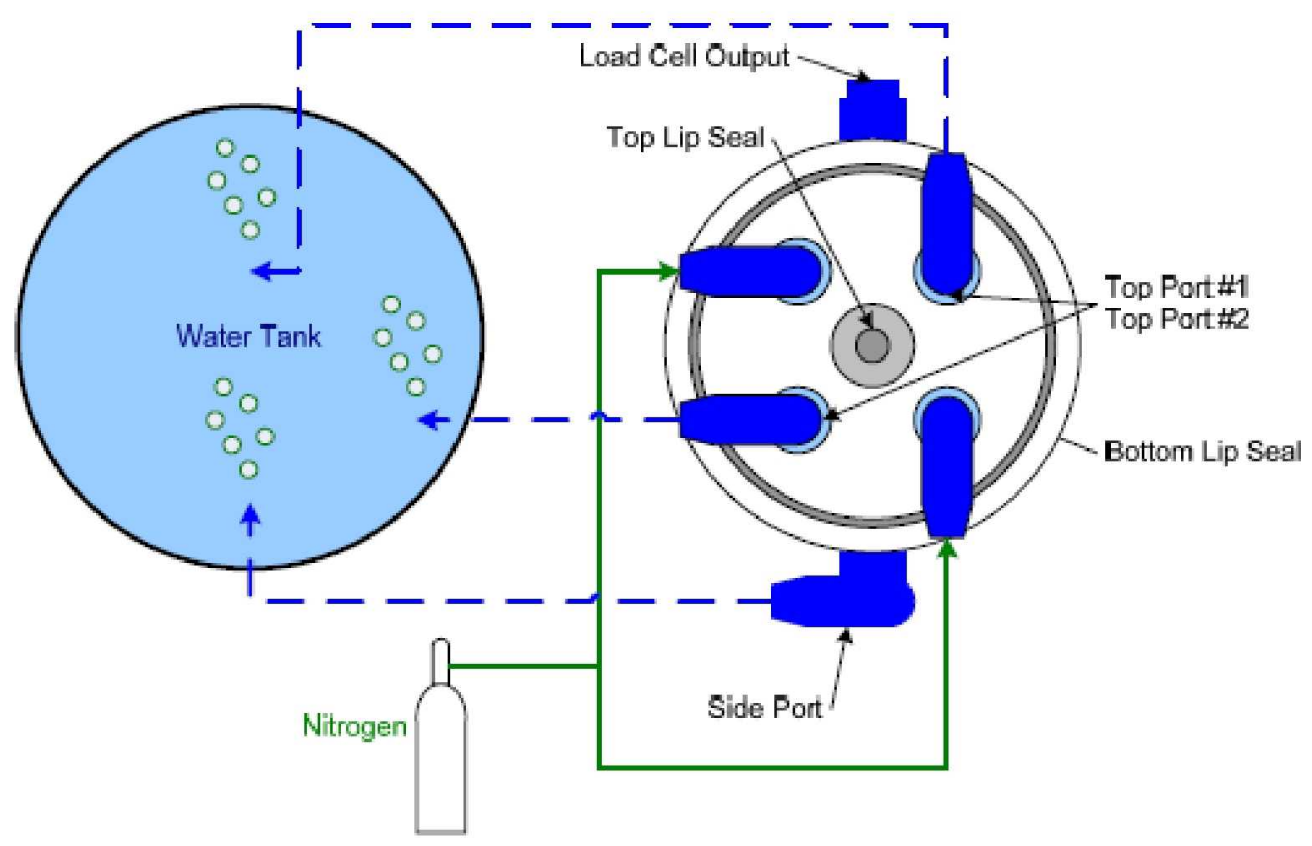

Figure 14. Initial TA4 face seal leak test rig.

During this testing, there were concerns that the face seal would be damaged by excessive actuation. Therefore, the running and breakaway torques were measured only for the clamping force in which no gas leakage was observed and for two lower clamping loads. There were too many bubbles to collect and measure the leak rate with the graduated cylinders. Therefore, the graduated cylinders were removed when performing test objectives 1 and 2 of Phase 1 testing and no quantitative leak rates were determined. Instead, leak detection fluid was used to detect leaks from the top and bottom lip seals, and "acceptable" leakage was defined as no bubbles produced by either of the top ports and side port in five minutes. Per this definition of "acceptable" leakage, TA4 continued to measure unacceptable leakage from the top lip seal and the side port locations when pressurized to $4.3-4.8 \mathrm{psig}$ and loaded to 43.4 lbf. This leakage lead to suspending the TA4 testing above a clamping force of $43.4 \mathrm{lbf}$ at $4.3-4.8$ psig. Testing the TA4 unit at 16 psig resulted in no leakage observed at a load cell force of $93.1 \mathrm{lbf}$ (Table 
2). Analysis of the data (Table 3 and Figure 15) revealed that the running torques were consistent when the valve was cycled in both directions (from " $A$ " to " $B$ " and from " $B$ " to " $A$ "). However, the static torques showed no consistency in the direction in which the amine bed position indicator turned; therefore, for analysis purposes, these higher static torques were used instead of the running torques as conservative dynamic torques. After testing, the test article was disassembled and the face seal was inspected for damage. The face seal showed no significant damage when viewed under magnification.

Table 1. Results for Test Article 4 Observed Leakage at 4.3-4.8 psig Internal Pressure

\begin{tabular}{|c|c|c|c|c|c|c|}
\hline $\begin{array}{l}\text { Load Cell } \\
\text { Voltage }\end{array}$ & $\begin{array}{l}\text { Load Cell } \\
\text { Load }\end{array}$ & \multicolumn{5}{|c|}{ Leakage Locations } \\
\hline$(\mathrm{mV})$ & $\left(\mid b_{i}\right)$ & $\begin{array}{c}\text { Top Port } \\
\# 1\end{array}$ & $\begin{array}{c}\text { Top Port } \\
\# 2\end{array}$ & $\begin{array}{l}\text { Side Port } \\
\text { (Port \#3) }\end{array}$ & $\begin{array}{c}\text { Top Lip } \\
\text { Seal }\end{array}$ & $\begin{array}{l}\text { Bottom } \\
\text { Lip Seal }\end{array}$ \\
\hline 0.53 & 16.6 & no leakage & no leakage & $x$ & no leakage & no leakage \\
\hline 0.71 & 22.2 & no leakage & no leakage & $x$ & $x$ & no leakage \\
\hline 0.9 & 28.1 & no leakage & no leakage & $\mathbf{x}$ & $x$ & no leakage \\
\hline 1.06 & 33.1 & no leakage & no leakage & $x$ & $x$ & no leakage \\
\hline 1.22 & 38.1 & no leakage & no leakage & $x$ & $x$ & no leakage \\
\hline 1.39 & 43.4 & no leakage & no leakage & $x$ & $\mathrm{x}$ & no leakage \\
\hline
\end{tabular}

Table 2. Results for Test Article 4 Observed Leakage at 16.0 psig Internal Pressure

\begin{tabular}{|c|c|c|c|c|c|c|}
\hline \multirow{2}{*}{$\begin{array}{c}\text { Load Cell } \\
\text { Voltage } \\
\text { (mV) }\end{array}$} & \multirow{2}{*}{$\begin{array}{l}\text { Load Cell } \\
\text { Load } \\
\left(\mathrm{Ib}_{\mathrm{f}}\right)\end{array}$} & \multicolumn{5}{|c|}{ Leakage Locations } \\
\hline & & $\begin{array}{c}\text { Top Port } \\
\# 1\end{array}$ & $\begin{array}{c}\text { Top Port } \\
\# 2\end{array}$ & $\begin{array}{l}\text { Side Port } \\
\text { (Port \#3) }\end{array}$ & $\begin{array}{c}\text { Top Lip } \\
\text { Seal }\end{array}$ & $\begin{array}{l}\text { Bottom } \\
\text { Lip Seal }\end{array}$ \\
\hline 1.06 & 33.1 & no leakage & $x$ & $x$ & $x$ & \\
\hline 1.22 & 38.1 & no leakage & $x$ & $x$ & $x$ & no leakage \\
\hline 1.39 & 43.4 & no leakage & $x$ & $x$ & $x$ & no leakage \\
\hline 1.53 & 47.8 & no leakage & $x$ & $x$ & $x$ & no leakage \\
\hline 1.69 & 52.8 & no leakage & $x$ & $x$ & $x$ & no leakage \\
\hline 1.84 & 57.5 & no leakage & $x$ & $x$ & $x$ & no leakage \\
\hline 2.01 & 62.8 & no leakage & $x$ & $x$ & $x$ & no leakage \\
\hline 2.16 & 67.5 & no leakage & $x$ & $x$ & $x$ & no leakage \\
\hline 2.33 & 72.8 & no leakage & $x$ & $x$ & $x$ & no leakage \\
\hline 2.49 & 77.8 & no leakage & no leakage & $x$ & $x$ & no leakage \\
\hline 2.65 & 82.8 & no leakage & no leakage & $x$ & $x$ & no leakage \\
\hline 2.82 & 88.1 & no leakage & no leakage & $x$ & $x$ & no leakage \\
\hline 2.98 & 93.1 & no leakage & no leakage & no leakage & no leakage* & no leakage \\
\hline
\end{tabular}


Table 3. Test Article 4 Observed Torque as a Function of Clamping Force at 16.0 psig Internal Pressure

\begin{tabular}{|c|c|c|c|c|c|}
\hline \multirow[t]{2}{*}{$\begin{array}{c}\text { Load Cell } \\
\text { Voltage } \\
\text { (mV) }\end{array}$} & \multirow[t]{2}{*}{$\begin{array}{l}\text { Load Cell } \\
\text { Load } \\
\left(\mid b_{f}\right)\end{array}$} & \multicolumn{2}{|c|}{$\begin{array}{c}\text { Static Torque } \\
\left.\text { (in- } \mid b_{1}\right)\end{array}$} & \multicolumn{2}{|c|}{$\begin{array}{l}\text { Running } \\
\text { Torque } \\
\left.\text { (in-l } \mid b_{j}\right)\end{array}$} \\
\hline & & $A$ to $B$ & $B$ to $A$ & $A$ to $B$ & $B$ to $A$ \\
\hline 1.09 & 34.1 & 20 & 20 & 10 & 10 \\
\hline 2.04 & 63.8 & 35 & 60 & 20 & 25 \\
\hline 2.98 & 93.1 & 90 & 140 & 60 & 70 \\
\hline
\end{tabular}

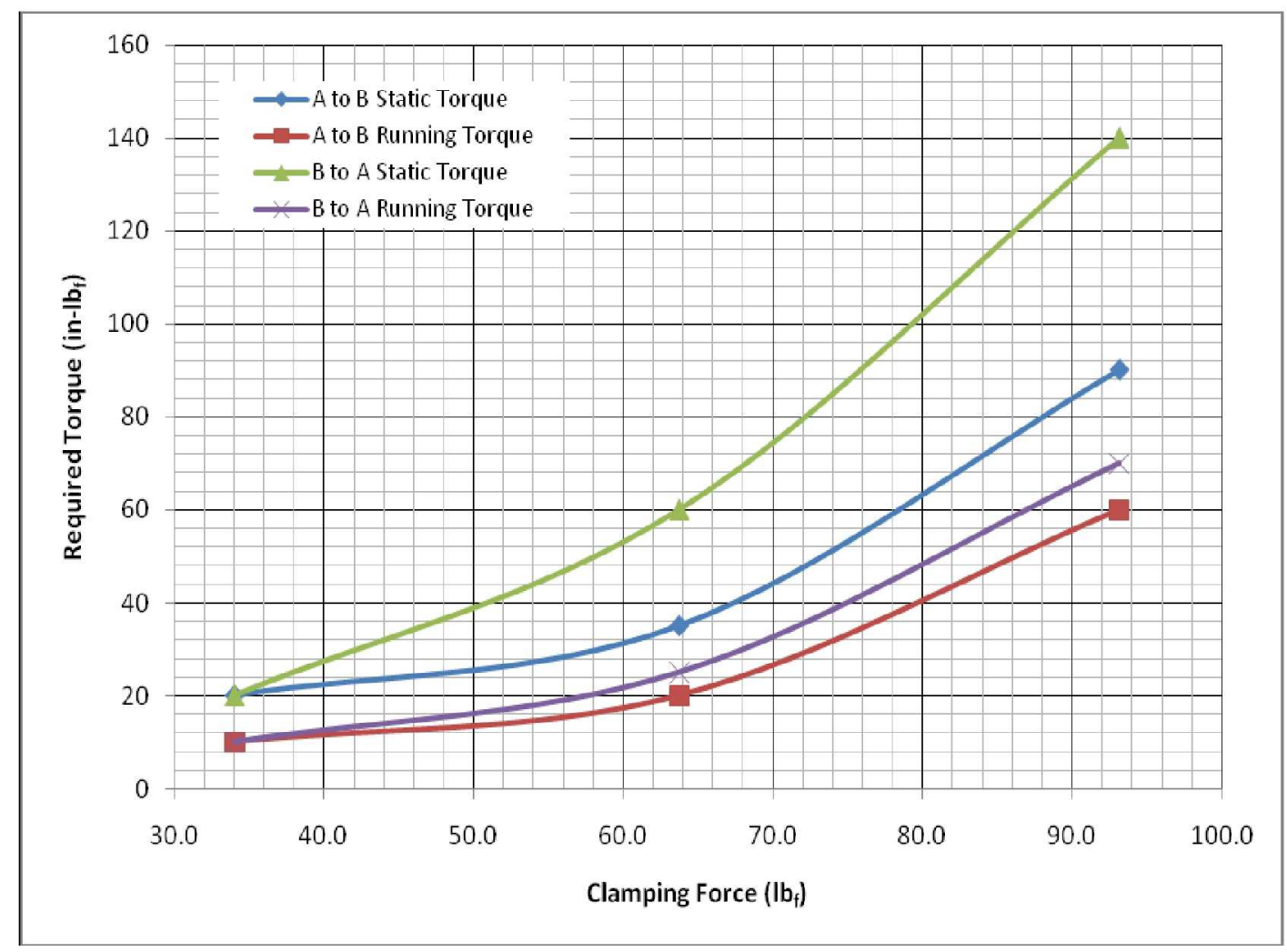

Figure 15. Test Article 4 bed actuation torque as a function of clamping force.

Due to the leakage issues encountered in Phase 1 testing, Phase 2 was initiated to fix the exterior seal leaks and re-assess the clamping force and torque values. In addition, compression set and load deflection testing were conducted to characterize the seal material.

Similar to Phase 1, to evaluate the external seal integrity TA4 was pressurized to 16 psig and then to 4.8 psig. At both pressures the test article was submerged in water. Again, the inverted graduate cylinders in a tank of water were used to quantify the leak rate. Initially, this test revealed that the bottom lip seal leaked at a rate of $11 \mathrm{cc}$ per 3 minutes, and the top lip seal leaked at a relatively small rate of $1 \mathrm{cc}$ in 15 minutes [4]. TA4 was disassembled and inspection revealed an gap between the diameters of the clamping bolt and the bottom lip seal. The outside diameter of the clamping bolt was 0.499 in, but the 
inner diameter of the bottom lip seal was $0.5 \mathrm{in}$. The bottom lip seal was replaced and leakage was eliminated. The small leakage rate of $1 \mathrm{cc}$ in 15 minutes was deemed as an "acceptable" leakage rate for the top lip seal; therefore, no lip seal replacement was required.

Once the external seal integrity test was completed with very little to no leakage from the TA4 exterior seals, the Phase 2 clamping force and torque testing was conducted. The test rig pressure was set to 4.8 psig and the clamping force to $34 \mathrm{lbf}$. The hexagonal bolt was rotated from " $A$ " to " $B$ " and the running torque was recorded using a digital torque meter connected to the torque wrench. After recording the leakage, the same process was repeated to identify the torque required to rotate the hexagonal bolt from " $B$ " to " $A$ ". This process was repeated at ten additional clamping forces ranging from $40 \mathrm{lbf}$ to 94 lbf, in increments of $6 \mathrm{lbf}$ [4]. After all data points for $4.8 \mathrm{psig}$ were collected, the process was repeated with the test article pressurized to $16 \mathrm{psig}$. One cycle for each clamping force was evaluated to confirm the test data and repeatability of the torque values. The torque versus clamping force data is shown in Figure 16. The data is clustered into two groups: $4.8 \mathrm{psig}$ (upper region of graph) and $16 \mathrm{psig}$ (lower region of graph). The minimum running torque required to operate the rotary valve at $4.8 \mathrm{psig}$ was approximately $26 \mathrm{in}$-lbf, which is equivalent to $4.6 \mathrm{~J}$ of friction loss for every cycle [3]. The clamping force required on the face seal in Phase 2 testing at 4.8 psig was $60 \mathrm{lbf}$, and at 16 psig the clamping force was $86 \mathrm{lbf}[3]$.

Torque vs Load at $4.8 \mathrm{psi}$ and $16 \mathrm{psi}$

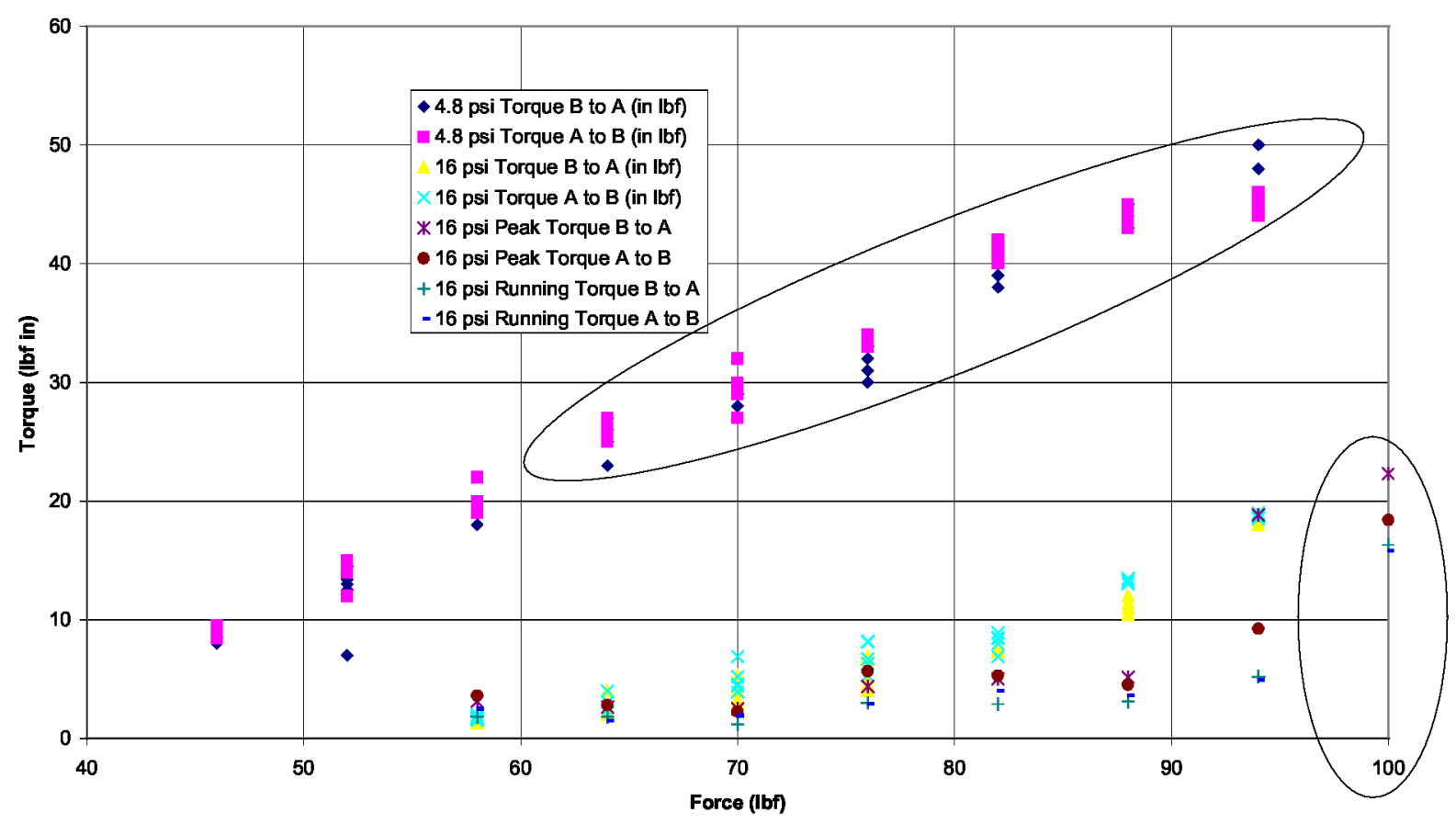

Figure 16. Torque vs. clamping force. Circled regions indicate data where no leakage was detected. 
After the clamping force and torque tests were completed, TA4 was disassembled and the face seal was inspected for damage in a similar manner as in Phase 1 . Once again, no visible damage was found when inspected under a magnification lens.

To characterize the face seal material, compression testing involving compression set and load deflection testing was completed in the NASA JSC Crew and Thermal Systems Division Advanced Materials Laboratory using a MTS/Instron ReNew Universal Testing machine and referring to ASTM D395-03 Method B to compression test each face seal. The compression loading tests measured deflection versus load, with the load being cycled several times. The compression set test measured each face seal recovery after holding a deflection for a specified time [3]. The seal (S/N 1004) used in Phase 1 torque/leak testing as well as a new seal (S/N 1005) was used for the compression cycle test and compression set test. The compression set testing was performed at a pre-determined $35 \%$ of the total seal height on the pristine Nitrile N406-60 face seal unit. With this testing approach, there would not be a need to run multiple compression set tests at different percentages; therefore, preserving the limited number of face seal valves available for the load deflection curve measurements. Two 35\% compression sets were performed on the pristine face seal ( $\mathrm{S} / \mathrm{N} 1005)$ and five $35 \%$ compression sets were performed on the used face seal (S/N 1004). It was estimated that the $35 \%$ compression loading was an appropriate compression level for the current valve development phase. Table 4 shows the results of the face seal compression set testing on both the pristine and used face seal. The compression sets on face seal S/N 1005 were conducted over a period of approximately 26 hours, whereas the compression sets on the new face seal (S/N 1004) were only held to 23.5 hours before it fully recovered [4].

Table 4. PLSS Rotary Seal Compression Set Test Results Summary

\begin{tabular}{|c|c|c|c|c|c|c|}
\hline Seal ID & $\begin{array}{c}\text { Cycle } \\
\text { No. }\end{array}$ & $\begin{array}{l}\text { Compression } \\
\text { Deflection } \\
\text { Level* }(\%) \\
\end{array}$ & $\begin{array}{c}\text { Compression } \\
\text { Duration } \\
\text { (hours) }\end{array}$ & $\begin{array}{c}\text { Recovery } \\
\text { Duration } \\
\text { (minutes) }\end{array}$ & $\begin{array}{c}\text { Set } \\
\text { Deflection } \\
\text { (in) }\end{array}$ & $\begin{array}{c}\text { Compression } \\
\text { Set }\end{array}$ \\
\hline \multirow{4}{*}{ S/N 1005} & \multirow{2}{*}{1} & \multirow{2}{*}{35} & \multirow{2}{*}{22} & 0 & 0.00591 & $18.2 \%$ \\
\hline & & & & 30 & 0.00020 & $0.6 \%$ \\
\hline & \multirow{2}{*}{2} & \multirow{2}{*}{35} & \multirow{2}{*}{18} & 0 & 0.00512 & $15.8 \%$ \\
\hline & & & & 30 & 0.00138 & $4.2 \%$ \\
\hline \multirow{10}{*}{$\begin{array}{l}\mathrm{S} / \mathrm{N} 1004 \\
\text { (Torque } \\
\text { Cycled) }\end{array}$} & \multirow{2}{*}{1} & \multirow{2}{*}{35} & \multirow{2}{*}{22} & 0 & 0.00433 & $12.9 \%$ \\
\hline & & & & 30 & 0.00098 & $2.9 \%$ \\
\hline & \multirow{2}{*}{2} & \multirow{2}{*}{35} & \multirow{2}{*}{0.5} & 0 & 0.00335 & $10.0 \%$ \\
\hline & & & & 30 & 0.00079 & $2.3 \%$ \\
\hline & \multirow{2}{*}{3} & \multirow{2}{*}{35} & \multirow{2}{*}{0.5} & 0 & 0.00374 & $11.1 \%$ \\
\hline & & & & 12 & 0.00098 & $2.9 \%$ \\
\hline & \multirow{2}{*}{4} & \multirow{2}{*}{35} & \multirow{2}{*}{0.5} & 0 & 0.00335 & $10.0 \%$ \\
\hline & & & & 10 & 0.00098 & $2.9 \%$ \\
\hline & \multirow{2}{*}{5} & \multirow{2}{*}{35} & \multirow{2}{*}{0.5} & 0 & 0.00335 & $10.0 \%$ \\
\hline & & & & 10 & 0.00098 & $2.9 \%$ \\
\hline
\end{tabular}

The load versus deflection testing was conducted prior to the torque tests and again after completing the torque tests. The face seal was placed in the MTS/Instron machine, which slowly applied load at $0.01 \mathrm{in} / \mathrm{min}$ while measuring the compression until the face seal was $100 \%$ fully compressed (Figure 17) $[3,4]$. The targeted and actual deflection results from the compression cycle testing conducted on the torque/cycled face seal as well as the new face seal are shown in Table 5 and Figures 18 through 20. 


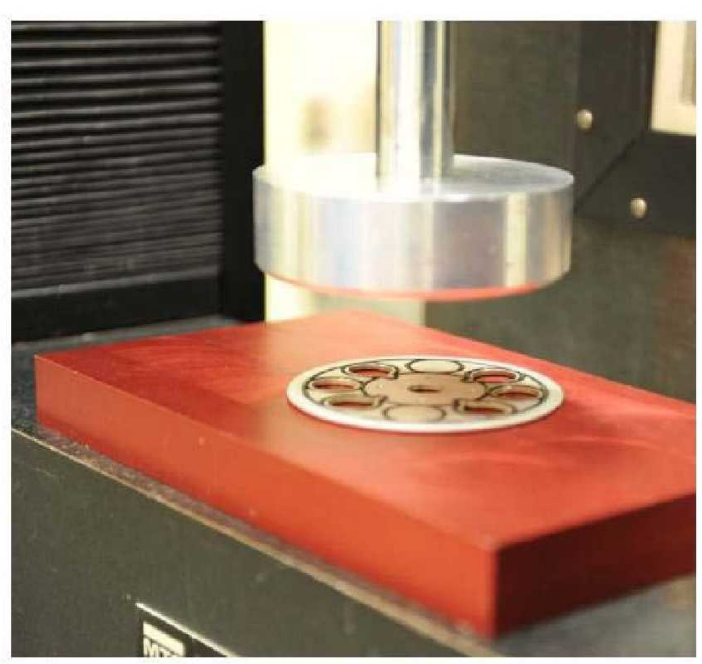

Figure 17. A TA4 Nitrile N406-60 face seal placed on the Instron for compression testing.

Table 5. PLSS RCA Rotary Seal Compression Deflection Cycle Test Data Summary

\begin{tabular}{|c|c|c|c|c|c|c|}
\hline Seal ID & $\begin{array}{l}\text { Cycle } \\
\text { No. }\end{array}$ & $\begin{array}{l}\text { Target Compression } \\
\text { Deflection Level (\%) }\end{array}$ & $\begin{array}{c}\text { Initial Seal } \\
\text { Thickness } \\
\text { (in) }\end{array}$ & $\begin{array}{l}\text { Actual Max } \\
\text { Compressed } \\
\text { Thickness (in) }\end{array}$ & $\begin{array}{c}\text { Actual } \\
\text { Compression Level }\end{array}$ & $\begin{array}{l}\text { Max Load } \\
\text { (lbf) }\end{array}$ \\
\hline \multirow{5}{*}{$\begin{array}{c}\text { S/N } 1004 \\
\text { (Torque } \\
\text { Cycled Seal) }\end{array}$} & 1 & 95 & 0.03031 & 0.02599 & $85.7 \%$ & 273.60 \\
\hline & 2 & 95 & 0.03031 & 0.02559 & $84.4 \%$ & 271.72 \\
\hline & 3 & 95 & 0.03031 & 0.02559 & $84.4 \%$ & 271.74 \\
\hline & 4 & 95 & 0.03031 & 0.02520 & $83.1 \%$ & 271.09 \\
\hline & 5 & 95 & 0.03031 & 0.02519 & $83.1 \%$ & 270.27 \\
\hline \multirow{7}{*}{$\begin{array}{c}\text { S/N } 1004 \\
\text { (Torque } \\
\text { Cycled Seal) }\end{array}$} & 6 & 98 & 0.03189 & 0.02894 & $90.7 \%$ & 330.93 \\
\hline & 7 & 100 & 0.03189 & 0.02973 & $93.2 \%$ & 348.11 \\
\hline & 8 & 100 & 0.03189 & 0.03071 & $96.3 \%$ & 373.36 \\
\hline & 9 & 100 & 0.03189 & 0.03170 & $99.4 \%$ & 399.61 \\
\hline & 10 & 100 & 0.03189 & 0.03268 & $102.5 \%$ & 427.41 \\
\hline & 11 & 100 & 0.03189 & 0.03366 & $105.6 \%$ & 458.91 \\
\hline & 12 & 100 & 0.03189 & 0.03465 & $108.7 \%$ & 489.68 \\
\hline \multirow{5}{*}{$\begin{array}{c}\text { S/N } 1002 \\
\text { (New Seal) }\end{array}$} & 1 & 100 & 0.03209 & 0.03228 & $100.6 \%$ & 505.68 \\
\hline & 2 & 100 & 0.03209 & 0.03228 & $100.6 \%$ & 499.54 \\
\hline & 3 & 100 & 0.03209 & 0.03228 & $100.6 \%$ & 497.18 \\
\hline & 4 & 100 & 0.03209 & 0.03228 & $100.6 \%$ & 495.41 \\
\hline & 5 & 100 & 0.03209 & 0.03228 & $100.6 \%$ & 495.02 \\
\hline
\end{tabular}




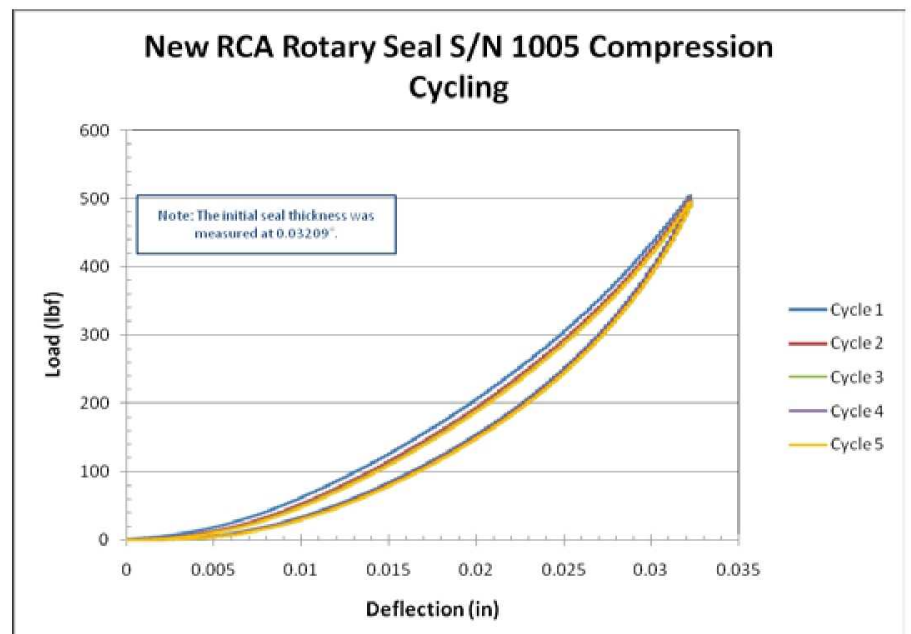

Figure 18. Compression cycle testing on a new TA4 face seal (S/N 1002)

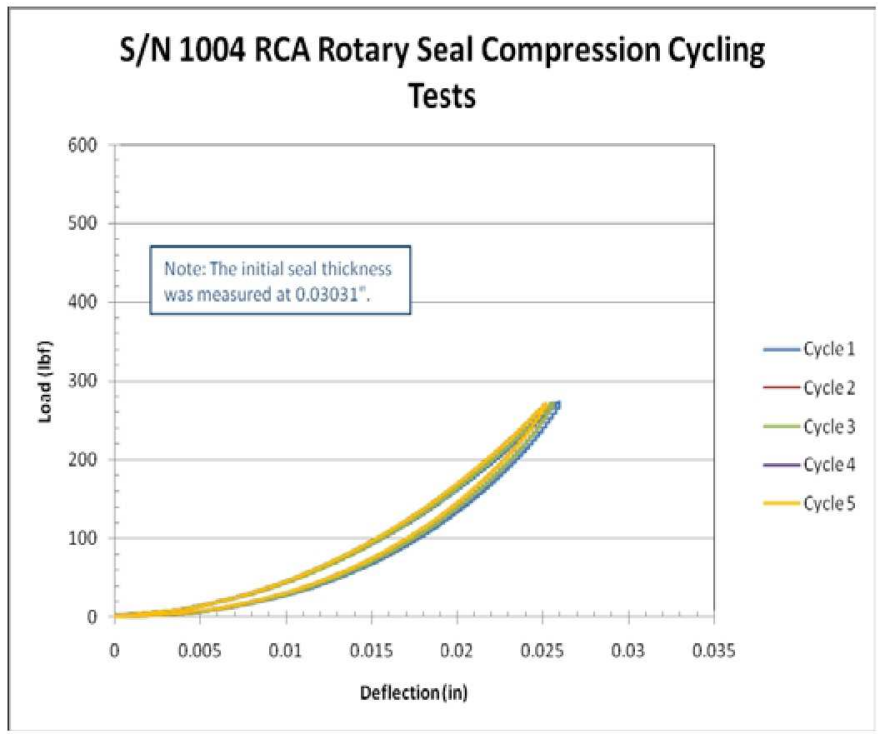

Figure 19. Five cycles for the compression test on the torqued/cycled TA4 face seal (S/N 1004)

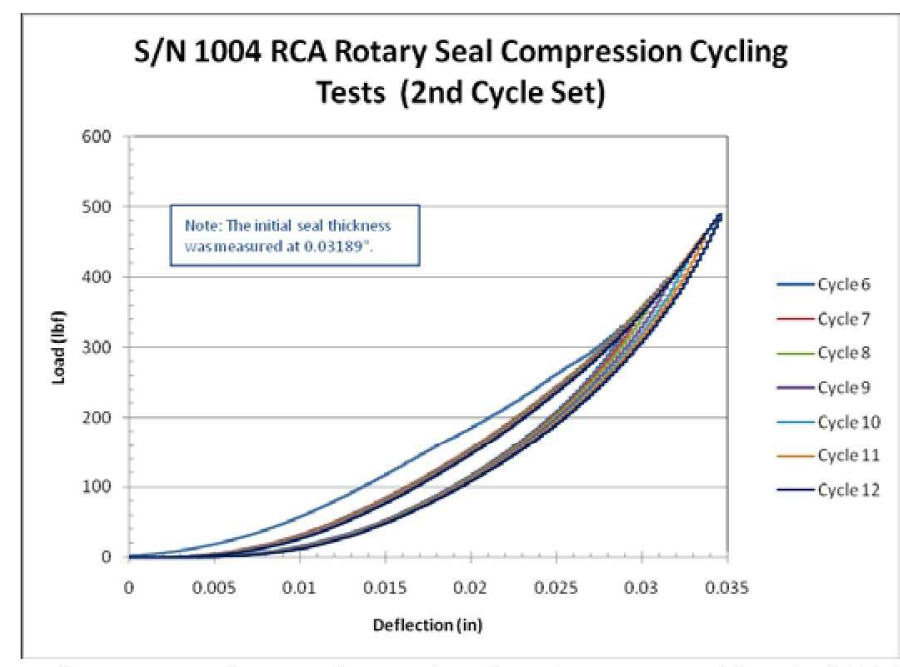

Figure 20. Second set of compression cycle testing for the torqued/cycled TA4 face seal (S/N 1004) 


\section{RCA Drive System Trade Study}

The RCA drive system trade study [7] was a feasibility study to evaluate potential drive systems that would rotate the RCA system, using test results from TA4. This trade study was initiated due to a concern that while the face seal valve design looked feasible from initial test results, the motor necessary to drive the face seal rotation could exceed mass and power allowances for the RCA assembly. This study took into account design goals of the drive system, drive system components, and outlined a candidate list of potential drive systems.

\section{Valve Cycle and Half Cycle Duration Analysis}

The initial analysis of this study was a design optimization to trade the power required of the system against valve cycle time. This analysis evaluated the impacts of RCA rotational valve cycling time on $\mathrm{CO}_{2}$ output, and recommended the half cycle duration for the RCA and the valve cycle duration. Calculations were completed using Excel. The calculated results were compared with TA4 test results. To generate RCA half cycle plots of $\mathrm{CO}_{2}$ concentration versus time, the worst-case scenario of a minimum suit volume of 0.0566 cubic meters $\left(\mathrm{m}^{3)}\right.$ ( 2 cubic feet $\left(\mathrm{ft}^{3}\right)$ ) based on the estimated space suit free volume, was assumed. A range of volumetric flow rates were evaluated to bound the low, middle, and high flow rate cases: $1.89 \times 10^{-3}, 2.36$ $\times 10^{-3}, 2.83 \times 10^{-3} \mathrm{acms}(4,5,6 \mathrm{acfm})$. Half cycle durations of one, two, and three minutes and valve cycle durations of one, five, ten, and fifteen seconds were analyzed. For these cases, a series of tables were generated to outline the average and peak $\mathrm{CO}_{2}$ concentrations, and these values were compared to the maximum allowable $\mathrm{CO}_{2}$ concentrations, per the EVA Space Suit Element Requirements Document, CSSE 3025 [8].

The following assumptions were included in this analysis:

- Crewmember (CM) trace gas production was neglected

- RCA trace gas production was neglected

- All leakages were neglected (suit, $\mathrm{CO}_{2}$ sensor, and $\mathrm{RCA}$ vented gases)

- $100 \%$ suit mixing

- $\quad$ Suit pressure $=29.7 \times 10^{3}$ pascal (pa) ( 4.3 pounds per square inch - absolute (psia))

- $\quad 100 \%$ RCA bypass during bed equalization

- $0 \%$ water $\left(\mathrm{H}_{2} \mathrm{O}\right)$ liquid and vapor

- Mass balance: \# moles $\mathrm{CM}$ oxygen $\left(\mathrm{O}_{2}\right)$ consumption = \# moles $\mathrm{CM} \mathrm{CO}_{2}$ production

- \# moles carbon dioxide $\left(\mathrm{CO}_{2}\right)$ absorbed by $\mathrm{RCA}=$ \# moles $\mathrm{O}_{2}$ supplied by primary oxygen apparatus (POA)

- Isothermal system

- $\quad$ RCA bed volume (SA9T volume) $=715$ cubic centimeters $\left(\mathrm{cm}^{3}\right)\left(2.53 \times 10^{-2}\left(\mathrm{ft}^{3}\right)\right.$

- CM met rate was set to 469 watts (W) (1600 British thermal units per hour (Btu/hr))

- Time step set for 1 second for all durations

- Flow rate was constant 
To conduct this analysis, the $\mathrm{CO}_{2}$ removal efficiency (Equation 1) and the $\mathrm{CO}_{2}$ production rate (Equation 2) were used, as well as the ideal gas law. Equation 1 was derived from a combination of performance models built from HS RCA and the vehicle-designed $\mathrm{CO}_{2}$ and $\mathrm{H}_{2} \mathrm{O}$ control system test data. Since testing of the HS RCA was only conducted at 6 acfm, data had to be correlated for the 4 and 5 acfm flow rates. As Equation 1 shows, the $\mathrm{CO}_{2}$ removal efficiency ( $\left.h_{(\mathrm{CO} 2 \text { removal) }}\right)$ is a function of the molar fraction of $\mathrm{CO}_{2}\left(\mathrm{M}_{\mathrm{CO} 2}\right)$; the RCA inlet pressure ( $\mathrm{P}_{\text {in }}$ [bar]) which was set to the suit pressure; the time from beginning of the RCA half cycle $\left(t_{c}\right.$, current time [hr] $-t_{h c}$, beginning of half cycle [hr], set to zero); the SA9T bed volume $\left(V_{b} / 715=B e d\right.$ volume / $\left.715 \mathrm{~cm}^{3}\right)$; the volumetric flow rate $\left(\mathrm{V}_{\mathrm{f}}\left[\mathrm{m}^{3} / \mathrm{hr}\right]\right)$; and the number of RCA units $\left(\mathrm{N}_{\mathrm{u}}\right)$.

Equation 1:

$\mathrm{h}_{(\mathrm{CO} 2 \text { removal })}=$

$100 * 1.2954$

$\left.\left.\left(\left(0.029277^{*} \mathrm{M}_{\mathrm{CO2}}{ }^{*} \mathrm{P}_{\text {in }} /((3 / 760) * 1.01325)\right)^{1.5}\right) * 60 *\left(\mathrm{t}_{\mathrm{c}}-\mathrm{t}_{\mathrm{hc}}\right)^{*}\left(\left(\mathrm{~V}_{\mathrm{b}} / 715^{*} \mathrm{~F}_{\mathrm{v}} / \mathrm{N}_{\mathrm{u}}\right) /(6.15 * 0.028317 * 60)\right)+1.2954\right)^{2}\right)$

Equation 2 calculates the crewmember $\mathrm{CO}_{2}$ production rate, which is a function of metabolic rate. The $\mathrm{CO}_{2}$ Consumption and Generation Rates (Figure 21) shows the crew oxygen consumption and carbon dioxide generation rates for metabolic rates and respiratory quotients [8]. For this equation, $\mathrm{RQO}_{2}$ is the $\mathrm{O}_{2}$ respiratory quotient, which was set to 0.82 and corresponds to the EVA ERD requirement for oxygen supply rate from the PLSS (CSSE3047) [8]. The metabolic rate (RM) was set to $1600 \mathrm{Btu} / \mathrm{hr}$ per the assumptions. The $\mathrm{CO}_{2}$ respiratory quotient $\left(\mathrm{RQCO}_{2}\right)$ was set to 0.92 , per the EVA ERD requirement CSSE3052 [8].

Equation 2:

$\mathrm{CO}_{2}$ production rate $=\underline{\left(0.000718-\left(\left(\mathrm{RQO}_{2}-0.707\right) / 0.273 * 0.0000123\right)\right) * \mathrm{RM} * 44.0}$

\section{$32.0 * \mathrm{RQCO}_{2}$}

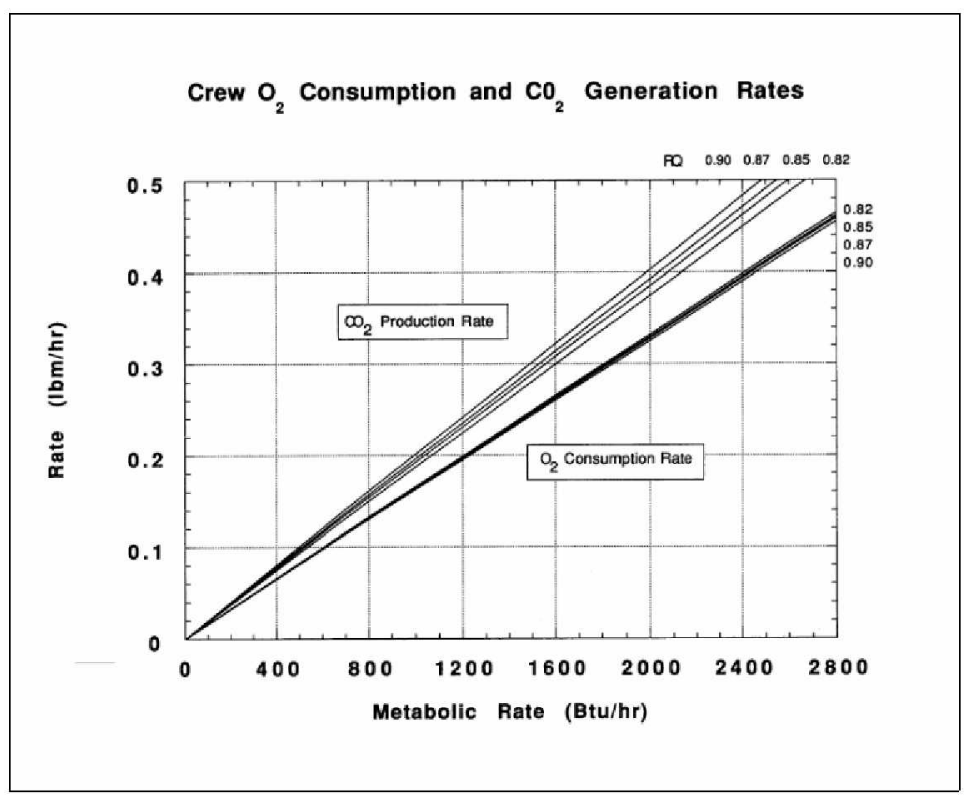

Figure 21. $\mathrm{CO}_{2}$ Consumption and Generation Rates 
Table 6 shows the cyclical steady state results. Comparing analysis results to HS RCA test results, HS RCA testing resulted in $4.5 \mathrm{mmHg} \mathrm{CO}$ average helmet inlet for $2.83 \times 10-3$ acms (6 acfm), $469 \mathrm{~W}(1600 \mathrm{Btu} / \mathrm{hr})$ metabolic rate so this is within $5 \%$ of the test data. Data under 7.6 $\mathrm{mmHg}$ (highlighted in Table 6) meets the ERD requirement for $\mathrm{CO}_{2}$ partial pressure up to and including $1600 \mathrm{Btu} / \mathrm{hr}$ (CSSE3025 [8]).

Table 6. Cyclical Steady-State Analysis Results

\begin{tabular}{|c|c|c|c|c|c|}
\hline \multicolumn{6}{|c|}{4 ACFM- Average $\mathrm{CO}_{2}$ Helmet Inlet Concentration $(\mathrm{mmHg})$} \\
\hline & & \multicolumn{4}{|c|}{ Valve Cycle Duration (sec) } \\
\hline & & 1 & 5 & 10 & 15 \\
\hline \multirow{3}{*}{$\begin{array}{l}\text { Half Cycle Duration } \\
\text { (min) }\end{array}$} & 1 & 4.91 & 6.06 & 7.69 & 9.82 \\
\hline & 2 & 7.85 & 8.42 & 9.29 & 10.31 \\
\hline & 3 & 15.39 & 16.02 & 16.91 & 17.93 \\
\hline \multicolumn{6}{|c|}{5 ACFM- Average $\mathrm{CO}_{2}$ Helmet Inlet Concentration $(\mathrm{mmHg})$} \\
\hline & & \multicolumn{4}{|c|}{ Valve Cycle Duration (sec) } \\
\hline & & 1 & 5 & 10 & 15 \\
\hline \multirow{3}{*}{$\begin{array}{l}\text { Half Cycle Duration } \\
\text { (min) }\end{array}$} & 1 & 3.77 & 4.61 & 5.91 & 7.45 \\
\hline & 2 & 5.64 & 6.09 & 6.69 & 7.46 \\
\hline & 3 & 9.66 & 10.00 & 10.47 & 11.00 \\
\hline \multicolumn{6}{|c|}{6 ACFM- Average $\mathrm{CO}_{2}$ Helmet Inlet Concentration $(\mathrm{mmHg})$} \\
\hline & & \multicolumn{4}{|c|}{ Valve Cycle Duration (sec) } \\
\hline & & 1 & 5 & 10 & 15 \\
\hline \multirow{3}{*}{$\begin{array}{l}\text { Half Cycle Duration } \\
\text { (min) }\end{array}$} & 1 & 3.04 & 3.73 & 4.84 & 6.07 \\
\hline & 2 & $4.37^{*}$ & 4.71 & 5.22 & 5.82 \\
\hline & 3 & 7.07 & 7.29 & 7.62 & 7.98 \\
\hline
\end{tabular}

Based on the results of this analysis, the following conclusions and recommendations are made:

- RCA half cycle duration should be set to one minute to allow for reduced flow rates and expanded valve operation time. Note: Increased RCA oxygen losses 
due to reduced half cycle time have not been evaluated and should be considered in future PLSS schematic evaluations.

- Rotational valve operation time should be set to a 5-second maximum. Three seconds or less is preferred to maintain low $\mathrm{CO}_{2}$ concentrations.

- The next iteration of the analysis should include model upgrades to take into account suit leakage, $\mathrm{CO}_{2}$ sensor losses, RCA oxygen losses, and $\mathrm{H}_{2} \mathrm{O}$ production/humidity effects. Iterations should be done with the $\mathrm{O}_{2}$ POA supply to equal total pressure loss within suit.

- The model time step should be decreased to 0.1 seconds, re-run minimal suit volume case and re-correlate these cases to HS testing data.

- Further testing will provide more data at the 4 and 5 acfm flow rates. This analysis should be re-evaluated with this additional test data.

\section{Drive System Design Evaluation}

The purpose of the drive system design evaluation was to determine the goals required for a system that would drive the RCA valve, and to see what technology options exist for this design. Table 7 shows the goals, values, and sources for this evaluation.

Table 7. Drive System Design Study Details

\begin{tabular}{|c|c|c|}
\hline Goals & Value & Source \\
\hline Range of Motion & $\begin{array}{c}0 \text { to } 90 \text { degrees } \\
\text { (bidirectional, } \mathrm{A} \text { to } \mathrm{B} \text { ) }\end{array}$ & $\begin{array}{c}\text { Design } \\
\text { Requirement }\end{array}$ \\
\hline $\begin{array}{c}\text { Weight (resulting actuator } \\
\text { maximum) }\end{array}$ & $680 \mathrm{~g}(1.5 \mathrm{lb})$ & Calculation \\
\hline Starting Torque & $3.4 \mathrm{~N}-\mathrm{m}$ (30 in-lb) & [4] \\
\hline Running Torque & $2.3 \mathrm{~N}-\mathrm{m}(20 \mathrm{in}-\mathrm{lb})$ & [4] \\
\hline Voltage (input supply) & 28 VDC & $\begin{array}{c}\text { Power, } \\
\text { Communications, } \\
\text { Avionics, and } \\
\text { Informatics } \\
\text { Requirement }\end{array}$ \\
\hline $\begin{array}{l}\text { Power Consumption } \\
\text { (electrical maximum) }\end{array}$ & $40 \mathrm{~W}$ (1.4 amps) & $\begin{array}{c}\text { PCAI Power, } \\
\text { Communications, } \\
\text { Avionics, and } \\
\text { Informatics } \\
\text { Requirements }\end{array}$ \\
\hline Rotation Duration ( $\mathrm{A}$ to $\mathrm{B}$ ) & $\begin{array}{l}\text { 1-3 seconds preferred, } 5 \\
\text { seconds maximum }\end{array}$ & $\begin{array}{c}\text { Cycle Duration } \\
\text { Analysis } \\
\text { Recommendations }\end{array}$ \\
\hline Rate (resulting) & 5-15 RPM preferred, 3 RPM min & Calculation \\
\hline Dwell (hold time at A or B) & 1 minute & $\begin{array}{l}\text { Cycle Duration } \\
\text { Analysis }\end{array}$ \\
\hline
\end{tabular}




\begin{tabular}{|c|c|c|}
\hline $\begin{array}{c}\text { Duty Cycle (2-minute cycle, } 6 \\
\text { seconds of operation) }\end{array}$ & $5 \%$ & Recommendations \\
\hline Position Accuracy & $+/-1^{\circ}$ & $\begin{array}{c}\text { Colerance (Gap) } \\
\text { Analysis }\end{array}$ \\
\hline Pressure Range & $0-.11$ megapascal [MPa] $(0-16$ & $\begin{array}{c}\text { PLSS Schematic } \\
\text { psia) }\end{array}$ \\
\hline Temperature Range & $\begin{array}{c}-1 \text { degrees Celsius }\left[{ }^{\circ} \mathrm{C}\right] \text { to } 38^{\circ} \mathrm{C} \\
\left(30 \text { degrees Fahrenheit }\left[{ }^{\circ} \mathrm{F}\right] \text { to }\right. \\
\left.100^{\circ} \mathrm{F}\right)\end{array}$ & $\begin{array}{c}\text { PLSS Schematic } \\
\text { Analysis }\end{array}$ \\
\hline
\end{tabular}

\section{Drive Mechanism Selection}

A market survey was conducted to determine what technologies are used for drive mechanisms, and of those, which would work for this application. Table 8 shows the technologies evaluated for torque capability, weight/size capability, and reduction capability. Rate reduction will be beneficial for the drive system due to the torque and weight goals. The drive mechanisms highlighted in red were selected for further consideration, and after evaluation, planetary and harmonic drives were considered to be best for this application.

Table 8. Drive Mechanism Technologies Evaluated

\begin{tabular}{|c|c|c|c|}
\hline Mechanisms Investigated & Torque Capability & Weight/Size Capability & Reduction Capability \\
\hline Direct Drive & $\mathrm{X}$ & $\mathrm{X}$ & $\mathrm{X}$ \\
\hline Planetary Gearbox & $\mathrm{X}$ & $\mathrm{X}$ & $\mathrm{X}$ \\
\hline Spur / Helical Gearbox & $\mathrm{X}$ & $\mathrm{X}$ & $\mathrm{X}$ \\
\hline Worm Gearbox & $\mathrm{X}$ & $\mathrm{X}$ & $\mathrm{X}$ \\
\hline Harmonic Drive & $\mathrm{X}$ & $\mathrm{X}$ \\
\hline Cycloidal Drive & $\mathrm{X}$ & $\mathrm{X}$ & \\
\hline Linkage & $\mathrm{X}$ & $\mathrm{X}$ & $\mathrm{X}$ \\
\hline Belt / Chain / Variable & $\mathrm{X}$ & $\mathrm{X}$ & \\
\hline Hybrid Combination & $\mathrm{X}$ & & $\mathrm{X}$ \\
\hline
\end{tabular}

\section{Motor Selection}

Brushed direct current (DC) motors, brushless DC motors, stepper motors, piezoelectric rotational friction motors, and frameless motors were surveyed, and brushless direct current motors were selected for this application. These motor have been proven to be the best allaround motors for aerospace applications because of their long life, high torque, high 
efficiency, and low heat dissipation. Brushless DC motors often use a permanent magnet external rotor, three phases of driving coils, one or more hall effect sensors to sense the position of the rotor, and the associated drive electronics. They are commonly used in space applications due to high efficiency, reliability, and position feedback. Table 9 shows the details for the top three motor candidates chosen for this application.

Table 9. Motor Selection Details

\begin{tabular}{|c|c|c|c|c|c|c|c|}
\hline Manufacturer & Model & $\begin{array}{c}\text { Motor } \\
\text { Type }\end{array}$ & $\begin{array}{c}\text { Drive Type } \\
\text { And } \\
\text { Reduction }\end{array}$ & $\begin{array}{c}\text { Max } \\
\text { Torque } \\
\mathbf{N}-\mathbf{m} \\
\text { (in-lb) }\end{array}$ & Voltage & $\begin{array}{c}\text { Current } \\
\text { (A) } \\
@ \\
3.4 \text { N-m } \\
\text { (30 in-lb) } \\
\text { load }\end{array}$ & $\begin{array}{c}\text { Weight } \\
\text { g (lb) }\end{array}$ \\
\hline Faulhaber & $\begin{array}{c}3056 \\
30 / 1\end{array}$ & Brushless & $\begin{array}{c}\text { Planetary, } \\
418: 1\end{array}$ & $6.0(53)$ & 24 VDC & .722 & $\begin{array}{c}626 \\
(1.38)\end{array}$ \\
\hline $\begin{array}{c}\text { Harmonic } \\
\text { Drives }\end{array}$ & FHA-8C & Brushless & $\begin{array}{c}\text { Harmonic, } \\
100: 1\end{array}$ & $4.8(42)$ & 24 VDC & 1.25 & $\begin{array}{c}558 \\
(1.23)\end{array}$ \\
\hline Maxon & $\begin{array}{c}\text { EC-Max30 } \\
\text { GP32C }\end{array}$ & Brushless & $\begin{array}{c}\text { Planetary } \\
411: 1\end{array}$ & $6.0(53)$ & 24 VDC & .606 & $\begin{array}{c}612 \\
(1.35)\end{array}$ \\
\hline
\end{tabular}

$40 \mathrm{~W}=1.4$ Amps @ 28 V

Figure 22 shows, to scale, how the three candidates would be incorporated into the RCA assembly. TA4 is shown since that model was readily available at the time of this study. For the current assembly configuration, the Harmonic Drive is best because it has the lowest profile and mass of the three options, however further evaluations should take place to determine if this is truly the best technology for this application.

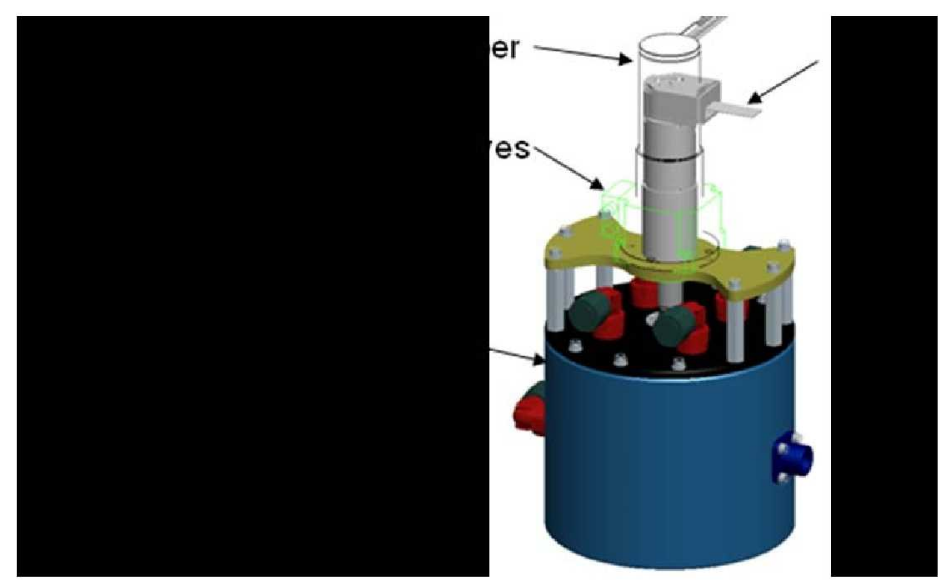

Figure 22. Three COTS candidates incorporated with TA4 for scale

Appropriate sizing of an electric drive system for the RCA will permit reliable operation, while minimizing weight and power consumption. These initial results look promising, however the 
survey only evaluated commercial-off-the-shelf technologies. A custom solution could be designed that would further reduce weight and power consumption. In addition, as the RCA canister and valve designs progress towards a lighter weight assembly, assuming that the RCA system weight allocation remains the same, the available weight allocation could be applied to the drive system, opening up further technology options. As design goals change through the development of the RCA system, there may be more opportunities to evaluate additional options for brushless direct current motors and drive mechanisms.

\section{Conclusions and Future work}

This paper provided an overview of the development efforts conducted at the NASA Johnson Space Center to redesign the RCA canister and valve assembly into a radial flow, cylindrical package for carbon dioxide and humidity control of the PLSS ventilation loop. Repackaging efforts led to the conceptual development and fabrication of four sub-scale test articles to evaluate risks identified with this low technology readiness level assembly.

The results of testing with the face seal test article, TA4, revealed that a face seal design is feasible, but these results are very preliminary and further design and testing is warranted to fully prove out this design. The valve is the highest risk portion of the RCA assembly, as it must cycle many times over the life of the RCA, and if it fails, it could subject the ventilation loop, and therefore the crewmember, to vacuum. As designs for the RCA progress, materials should be selected for oxygen compatibility and further torque testing should be conducted to evaluate the power required to drive the valve. In addition, life cycle testing will be critical to prove that the face seal can sustain cycling in the presence of contaminants and particulate.

Based on the TA4 test results, the RCA drive system trade study determined that three commercial-off-the-shelf motor/drive systems are currently available that could drive the RCA valve under the current requirements. As RCA assembly designs evolve and requirements mature, the drive system analysis and design should be revisited.

The technology readiness of these development efforts is still very low, so there is much work to be done to prove that a cylindrical RCA system with a face seal valve will work for an exploration space suit PLSS. In addition, requirements for the system are still evolving and should be followed closely as they will certainly drive design decisions in the future. The minimum flow rate requirement for the ventilation subsystem is 4 acfm (CSSE3024, [8]) which is low compared to current space suit designs. $\mathrm{A} \mathrm{CO}_{2}$ washout study [9] was initiated to determine if this lower flow rate would be sufficient to washout the carbon dioxide from the crewmember's oral nasal region as specified in CXP 70024 Human-Systems Integration Requirement $\mathrm{HS} 3005 \mathrm{C}$ [10]. The test data indicated a need for 2 to $2.3 \mathrm{mmHg} \mathrm{ppCO}$ at the helmet inlet as opposed to the $7.6 \mathrm{~mm} \mathrm{Hg}$ requirement, to account for mixing with the $\mathrm{CO}_{2}$ exhaled by the crewmember. When the performance data of the HS RCA unit was evaluated in this study, the average helmet inlet $\mathrm{ppCO}_{2}$ value was $4.5 \mathrm{mmHg}$ at $2.83 \times 10^{-3} \mathrm{acms}(6 \mathrm{acfm})$ with a 2-minute half cycle duration, so meeting the lower $\mathrm{CO}_{2}$ partial pressure requirement may prove to be challenging. It is important to note however, that this analysis is preliminary and is 
based on limited availability of flow rate-dependent RCA performance data at 6 acfm. RCA testing to be conducted in the PLSS Ventilation Laboratory at $1.89 \times 10^{-3}$ and $2.36 \times 10^{-3}$ acms (4 and $\mathbf{5}$ acfm) will provide additional data to determine if this is a valid concern.

\section{Acknowledgments}

The authors of this paper would like to thank the RCA design and analysis teams, whose various presentations, ideas, and analyses were compiled to write this paper.

\section{References}

1. Papale, W., H. Paul, and G. Thomas, "Development of Pressure Swing Adsorption Technology for Spacesuit Carbon Dioxide and Humidity Removal," 36th International Conference on Environmental Systems, SAE Paper Number 2006-01-2203, 2006.

2. Papale, W. and H. Paul, "Development Status of an EVA-sized Cycling Amine Bed System For Spacesuit Carbon Dioxide and Humidity Removal," 37th International Conference on Environmental Systems, SAE Paper Number 2007-01-3272, 2007.

3. Hanford, A. J., Pinckney, J. T., "Summary of Testing to Date for the Rapid Cycle Amine Test Articles," ESCG-4470-09-TEAN-DOC-0105-A, Engineering and Science Contract Group (ESCG), Houston, Texas, 28 August 2009.

4. Jennings, M., "Engineering Evaluation of ESCG RCA Test Article 4 Testing - Phase 2 Final Report," CTSD-ADV-739, National Aeronautics and Space Administration, Lyndon B. Johnson Space Center, Crew and Thermal Systems Division, Houston, Texas, 07 August 2009.

5. Dillon, P., "RCA Pathfinders - Outbrief," ESCG-4420-09-CED-DOC-0003-A, Engineering and Science Contract Group (ESCG), Houston, Texas, 30 July 2009. Internal NASA presentation.

6. CSSE PLSS RCA Drive System Trade Study (ESCG-4420-09-CED-DOC-004), Sept 30, 2009.

7. "Constellation Program Extravehicular (EVA) Systems Project Office (ESPO) Space Suit Element Requirements Document." CXP 72208, rev C.3, Houston: NASA/Johnson Space Center, September 22, 2009.

8. CO2 Washout Outbrief EDAC-3B, Philip Augustine, EVA SE\&I 19-Aug-09.

9. "Constellation Program Human-Systems Integration Requirements." CxP 70024, rev C, Houston: NASA/Johnson Space Center, March 6, 2009.

\section{Acronyms}

E

EBW

ESCG

EVA

CC

g in-lbf energy required to operate a valve

Electron Beam Welding

Engineering and Science Contract Group

extravehicular activity

cubic centimeters

gram (units of mass)

inch-pounds, force (units of torque) 


$\begin{array}{ll}\mathrm{J} & \text { Joules (units of energy) } \\ \mathrm{lbf} & \text { pounds, force (units of force) } \\ \mathrm{mL} / \mathrm{min} & \text { milliliters per minute (units of volumetric flow rate) } \\ \mathrm{mV} & \text { milli-volts (units of voltage) } \\ \mathrm{NASA} & \text { National Aeronautics and Space Administration } \\ \text { PLSS } & \text { portable life support system } \\ \text { psig } & \text { pounds (force) per square inch, gauge (units of pressure) } \\ \text { RCA } & \text { Rapid Cycle Amine } \\ \text { SA9T } & \text { Hamilton Sundstrand Amine-based sorbent } \\ \text { sec } & \text { second } \\ \text { TA1 } & \text { Test Article } 1 \text { (test article for end-cap joining methods) } \\ \text { TA2 } & \text { Test Article } 2 \text { (test article for static thermodynamic bed performance) } \\ \text { TA3 } & \text { Test Article } 3 \text { (test article for airflow evaluation) } \\ \text { TA4 } & \text { Test Article } 4 \text { (test article to evaluate face seal torque and clamping force) } \\ \alpha & \text { angle of rotation } \\ \tau & \text { torque } \\ \text { TRL } & \text { Technology Readiness Level }\end{array}$

